PONTIFÍCIA UNIVERSIDADE CATÓLICA DO RIO DE JANEIRO

\title{
A Influência das finanças pessoais na gestão financeira de microempresas
}

\section{Gabriela Pereira da Silva Catarino}

Trabalho de Conclusão de Curso

CENTRO DE CIÊNCIAS SOCIAIS - CCS

DePARTAMENTO de AdMINISTRAÇÃo

Graduação em Administração de Empresas 


\section{Gabriela Pereira da Silva Catarino}

\section{A Influência das finanças pessoais na gestão financeira de microempresas}

Trabalho de Conclusão de Curso

Trabalho de Conclusão de Curso, apresentado ao programa de graduação em Administração da PUC-Rio como requisito parcial para a obtenção do título de graduação em Administração.

Orientador(a) : Liana Ribeiro dos Santos 


\section{Resumo}

Catarino, Gabriela P. da S. A Influência das finanças pessoais na gestão financeira de microempresas. Rio de Janeiro, 2019. 51 p. Trabalho de Conclusão de Curso - Departamento de Administração. Pontifícia Universidade Católica do Rio de Janeiro.

O objetivo do trabalho foi analisar a influência das competências em finanças pessoais do microempreendedor na gestão financeira de uma microempresa. Para isso, foi realizada uma pesquisa exploratória e descritiva com 96 donos de microempresas localizadas na região metropolitana do Rio de Janeiro e que possuem mais de dois anos de funcionamento sob a mesma gestão. Utilizou-se de um questionário com perguntas fechadas para a coleta de dados e, a fim de cumprir o objetivo, esses foram analisados por meio da associação entre as duas variáveis qualitativas, competências em finanças pessoais e capacidade de gestão financeira, a partir de uma abordagem quantitativa. Encontrou-se a existência de relação entre as variáveis e, ainda que não tenha se mostrado forte, entende-se que as decisões relativas às finanças pessoais têm influência sobre as decisões financeiras da microempresa.

Palavras- chave: Finanças Pessoais, Gestão Financeira, Microempresas

\section{Abstract}

Catarino, Gabriela P. da S. The Influence of Personal Finances on the Financial Management of Microenterprises. Rio de Janeiro, 2019. 51 p. Trabalho de Conclusão de Curso - Departamento de Administração. Pontifícia Universidade Católica do Rio de Janeiro.

The objective of this study was to analyze the influence of microentrepreneur personal finances competences on the financial management of a microenterprise. For that, an exploratory and descriptive research was carried out with 96 owners of microenterprises located in the metropolitan region of Rio de Janeiro and that have more than two years of operation under the same management. $A$ questionnaire was used with closed questions for the data collection and, in order to fulfill the objective, these were analyzed through the association between the two qualitative variables, personal finance competences and financial management capacity, from a quantitative approach. The existence of a relationship between the variables was found and, although it was not shown to be strong, it is understood that decisions regarding personal finances have an influence on microenterprise financial decisions. 
Key-words: financial management, micro-enterprises, personal finance 


\section{Sumário}

1. Introdução 1

1.1. O problema 1

1.2. Objetivo 4

1.2.1 Objetivos Intermediários 4

1.3. Delimitação e foco do estudo 4

2. Referencial Teórico 6

2.1. Empreendedorismo 6

2.2. Gestão Financeira $\quad 7$

2.3. Finanças pessoais $\quad 8$

2.4. Gestão financeira pessoal 9

3. Metodologia 11

3.1. Método de pesquisa utilizado 11

3.2. Fontes de informação selecionadas para coleta de dados no estudo 11

3.3. Procedimentos e instrumentos de coleta de dados utilizados no estudo 11

3.4. Formas de tratamento e análise dos dados coletados para o estudo 12

3.5. Limitações da pesquisa 12

4. Apresentação e análise dos resultados 14

5. Conclusões 23

$\begin{array}{ll}\text { Referências Bibliográficas } & 25\end{array}$

$\begin{array}{ll}\text { Anexos } & 28\end{array}$

Anexo 1 - Questionário da pesquisa $\quad 28$

Anexo 2 - Gráficos com resultados da pesquisa 36 


\section{Lista de gráficos}

Gráfico 1 - Taxa de mortalidade de empresas de dois anos constituídas em 2012, por porte

$\begin{array}{ll}\text { Gráfico } 2 \text { - Percepção sobre o nível de qualificação } & 16\end{array}$

Gráfico 3 - Planejamento financeiro pessoal e demonstrações financeiras $\quad 17$

$\begin{array}{lr}\text { Gráfico } 4 \text { - Dívidas } & 18\end{array}$

$\begin{array}{lr}\text { Gráfico } 5 \text { - Dívidas em atraso } & 19\end{array}$

Gráfico 6 - Investimentos financeiros $\quad 20$

Gráfico 7 - Finalidade dos investimentos financeiros $\quad 21$

Gráfico 8 - Qual a sua faixa etária? 36

Gráfico 9-Qual seu sexo? $\quad 36$

Gráfico 10 - Qual a sua renda mensal? $\quad 37$

Gráfico 11 - Qual seu nível de escolaridade? $\quad 37$

$\begin{array}{ll}\text { Gráfico } 12 \text { - Já teve outros negócios? } & 37\end{array}$

Gráfico 13 - Por que fechou? 38

Gráfico 14 - Como se qualificou para fazer a gestão do negócio? 38

Gráfico 15 - Você separa as contas da empresa de suas contas pessoais? 39

Gráfico 16 - Quem faz a gestão financeira do negócio? 39

Gráfico 17 - As demonstrações financeiras são utilizadas para gerenciar o negócio? $\quad 40$

Gráfico 18 - Como você faz seu planejamento financeiro pessoal? $\quad 40$

Gráfico 19 - Quanto você se considera qualificado para fazer a gestão financeira do seu negócio? $\quad 41$

Gráfico 20 - Quanto você se considera qualificado para fazer uma boa gestão das suas finanças pessoais? 41

Gráfico 21 - A empresa possui dívidas? 42

Gráfico 22 - Você possui dívidas? 42

Gráfico 23 - A empresa possui dívidas em atraso? 43 
Gráfico 24 - Você possui dívidas em atraso?

Gráfico 25 - A empresa possui algum tipo de investimento financeiro? Se sim, qual(is)?

Gráfico 26 - Você possui algum tipo de investimento financeiro? Se sim, qual(is)?

Gráfico 27 - Qual a finalidade dos investimentos financeiros da empresa?

Gráfico 28 - Qual a finalidade dos investimentos financeiros pessoais? 


\section{Introdução}

\subsection{O problema}

O trabalho trata de dois grandes tópicos: gestão financeira e finanças pessoais, sendo esses delimitados ao âmbito das microempresas e seus respectivos microempreendedores. Por conseguinte, propõe-se a seguinte questão: As competências do microempreendedor no âmbito das finanças pessoais influenciam na gestão financeira do empreendimento? Para que se possa compreender o contexto do problema, há uma sequência de dados relativos à gestão de microempresas e à educação financeira no Brasil. A fim de que tornese possível estudar a relação entre eles.

Segundo a Global Entrepreneurship Monitor (GEM, 2016), a vontade de ter seu próprio negócio é maior do que buscar carreira em uma empresa nacional ou multinacional, por parte de pessoas com menor escolaridade. Ainda assim, o nível de educação empreendedora no ensino fundamental e médio é um dos principais pontos negativos para o desenvolvimento da atividade empreendedora por ser considerado baixo (GEM, 2016).

Ademais, o item educação e capacitação é considerado como fator limitante à abertura e manutenção de novos negócios e foi o segundo item mais recomendado $(49,5 \%)$ pelos especialistas para a melhoria das condições para empreender no Brasil (GEM, 2016). Ele "avalia até que ponto a capacitação para a criação ou gerenciamento de novos negócios é incorporada aos sistemas educacionais formais e de capacitação em todos os níveis" (GEM, 2016), no qual, certamente inclui gestão financeira.

Os negócios cujos donos atuam por conta própria apresentam uma participação de $85 \%$ entre todos os negócios, sendo a maioria (93\%) desses donos enquadrados na faixa de baixa escolaridade. $O$ que torna os negócios menos estruturados e complexos. 
As microempresas apresentaram uma taxa de mortalidade de $45 \%$ para negócios de 2 anos constituídos em 2012, de acordo com o Serviço Brasileiro de Apoio às Micro e Pequenas Empresas (SEBRAE, 2016). Elas apresentam estruturas menos organizadas e menor capital que empresas maiores (EPP, MdE e GdE), bem como estruturas menos flexíveis e com mais exigências burocráticas, quando comparada aos MEls. Portanto, acredita-se que seja essa a explicação para o fato das microempresas possuírem a pior taxa de mortalidade, conforme apresenta o gráfico 1 (SEBRAE, 2016).

\section{Taxa de mortalidade de empresas de dois anos constituídas em 2012, por porte}

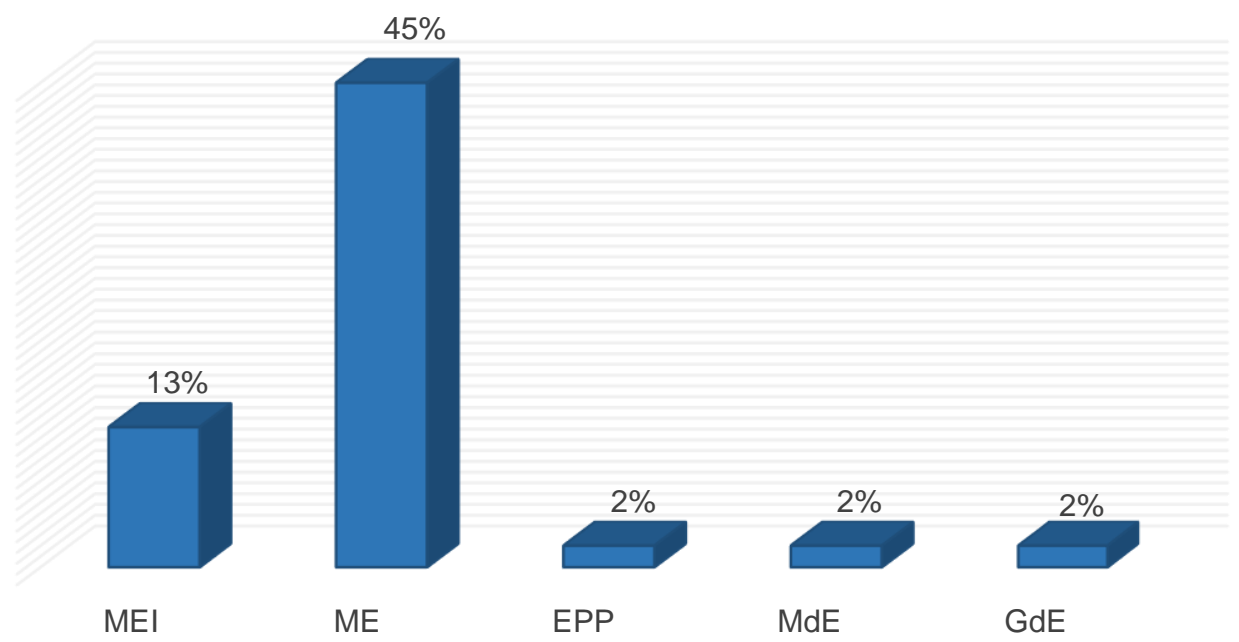

Gráfico 1 - Taxa de mortalidade de empresas de dois anos constituídas em 2012, por porte Fonte: SEBRAE, adaptado pela autora

Ao mesmo tempo que a defasagem na educação empreendedora é clara, compreende-se que o nível de educação financeira do brasileiro está muito abaixo do ideal. Segundo o levantamento sobre conhecimentos financeiros realizado pela Organização para a Cooperação e Desenvolvimento Econômico, (2016), o Brasil classificou-se na 27ª (vigésima sétima) colocação dentre trinta países. Dito isto, são inúmeras as decorrências da precariedade das competências referentes à educação financeira.

Somente $30 \%$ dos brasileiros possuem alguma reserva financeira (OCDE/Infe, 2016), logo, em caso de despesas inesperadas, 70\% das pessoas precisariam pedir dinheiro emprestado (OCDE/Infe, 2016), o que mostra a dificuldade dos brasileiros para lidar com imprevistos. Corroborando com isso, de acordo com Banco Central do Brasil (BCB, 2017), apenas 14,3\% afirmaram ser 
capazes de se manter por mais de 6 meses, sem fazer empréstimos, caso perdessem sua principal fonte de renda hoje. Esse fator é considerado de extrema importância na concepção de especialistas em finanças pessoais, Cerbasi (2009) o chama de Patrimônio Mínimo de Sobrevivência.

Também, pode-se afirmar que os brasileiros tendem a gastar mais do que ganham, dado que $50 \%$ tiveram a sensação de que suas despesas foram maiores que seus rendimentos (BCB, 2017). A explicação pode estar relacionada com o fato de que $56 \%$ não fazem orçamento doméstico (BCB, 2017).

Além disso, 60 milhões de pessoas no Brasil são inadimplentes, conforme pesquisa do Serviço de Proteção ao Crédito e da Confederação Nacional de Dirigentes Lojistas (SPC BRASIL, CNDL, 2018). Vale ressaltar que apenas $24,4 \%$ dos entrevistados nessa pesquisa sabem o correto significado de estar endividado: "ter parcelas a vencer de compras que foram divididas em prestações ou de empréstimos feitos" (SPC BRASIL, CNDL, 2018, p. 5), inclusive os brasileiros apresentam taxa média, para o período de 2005 à 2019, de 20\% de comprometimento da renda com pagamento de juros e amortizações (BCB, 2019).

Tais dados sinalizam a existência de certa defasagem na educação financeira da população brasileira. Inclusive, a informação mais interessante está relacionada ao quanto a população sente-se conhecedora de finanças e essa apresenta-se com um grau de confiança superior ao conhecimento efetivo (BCB, 2017).

Da mesma forma que a gestão financeira é extremamente importante para viabilizar e manter um empreendimento, as finanças pessoais tem a mesma função dentro de um lar. Antes mesmo de encarar o desafio de gerenciar um negócio, os microempreendedores lidam com suas finanças pessoais como qualquer outra pessoa que possui renda e despesas. Quando há aptidão e conhecimento para cuidar de seu dinheiro, as decisões são tomadas com qualidade significativamente superior. 


\subsection{Objetivo}

Diante de dados que relatam uma situação muito ruim quanto à educação financeira e à gestão de microempresas, pretende-se analisar a influência das competências em finanças pessoais do microempreendedor na gestão financeira de uma microempresa.

\subsubsection{Objetivos Intermediários}

Para isso, propõe-se:

- Verificar a situação financeira pessoal do microempreendedor;

- Verificar a situação financeira da microempresa;

- Avaliar como o microempreendedor faz a gestão de suas finanças pessoais;

- Avaliar como o microempreendedor faz a gestão financeira do seu negócio;

- Verificar como o empreendedor se capacitou;

- Verificar se as decisões financeiras pessoais são semelhantes às da empresa.

Espera-se encontrar uma relação entre a gestão das finanças pessoais e a gestão financeira das microempresas.

\subsection{Delimitação e foco do estudo}

O estudo é voltado às microempresas, cujos negócios apresentam faturamento anual igual ou inferior a $\mathrm{R} \$ 360.000,00$ (trezentos e sessenta mil reais) (Brasil, 14 DE DEZEMBRO DE 2006). A escolha de microempresas é devido à pior taxa de mortalidade dentre outros portes e, ao mesmo tempo, a maior participação no total de empresas, 89,3\% das empresas criadas em 2008 eram microempresas (SEBRAE, 2016).

Com relação à delimitação geográfica, a pesquisa abrange todos os negócios da região metropolitana do Rio de Janeiro. Pretende-se pesquisar as 
microempresas que possuem mais de dois anos de funcionamento sob a mesma gestão, pois esses já estão entre os $55 \%$ que sobreviveram aos dois primeiros anos (SEBRAE, 2016, p. 24) e já possuem dados e estrutura suficiente para contribuir com o trabalho. 


\section{Referencial Teórico}

\subsection{Empreendedorismo}

As bibliografias sobre empreendedorismo muitas vezes o define seguindo uma vertente de inovação, porém para os negócios pertencentes ao grupo delimitado pelo estudo faz-se necessário uma perspectiva mais ampla. Segundo a GEM, "entende-se como empreendedorismo qualquer tentativa de criação de um novo empreendimento, como, por exemplo, uma atividade autônoma, uma nova empresa ou a expansão de um empreendimento existente" (GEM, 2013, p. 3).

A GEM também categorizou o empreendedorismo em dois grupos, o empreendedorismo por necessidade e o empreendedorismo por oportunidade. $O$ primeiro é o caso de negócios que são criados como uma forma de se obter uma fonte de renda para a subsistência, já o segundo ocorre quando o empreendedor toma a decisão de abrir seu próprio negócio por enxergar uma oportunidade no mercado (GEM, 2013). Tais categorias são importantes, pois tem relação com a taxa de sobrevivência das empresas, visto que um negócio por necessidade tende a gozar de menos planejamento. Rogers (2011) expõe a falta de planejamento como um motivo do insucesso das empresas e afirma que "as pessoas primeiramente criam a empresa e só depois começam a obter informações sobre administração de fluxo de caixa, marketing, desenvolvimento de recursos humanos e outras áreas relacionadas ao trabalho." (ROGERS, 2011, p. 35).

Além disso, os donos de negócios podem ser divididos em Empregadores e Conta Própria. Este é a "pessoa que trabalha explorando o seu próprio empreendimento, sozinha ou com sócio, sem ter empregado e contando, ou não, com a ajuda de trabalhador não remunerado" (SEBRAE, 2015), logo, aquele trabalha com pelo menos um empregado remunerado (SEBRAE, 2015). Um dado interessante é a parcela de $93 \%$ de Conta Própria na faixa mais baixa de escolaridade, bem como, o fato de que conforme aumenta o nível de escolaridade, diminui a proporção dos donos de negócio que atuam por Conta Própria. Portanto, 
sabendo que os empreendimentos, cujos donos atuam por Conta Própria, dependem quase que exclusivamente de seus donos e apresentam estruturas menos complexas e/ou menor capital investido é possível associar à isso o baixo nível de escolaridade (SEBRAE, 2015).

\subsection{Gestão Financeira}

Pode-se dizer que o objetivo genérico da Administração Financeira é "ganhar dinheiro ou agregar valor para os proprietários" (ROSS, WESTERFIELD, JORDAN, LAMB, 2013, p. 8). Ademais, alguns objetivos financeiros são sobreviver, evitar problemas financeiros e falência (ROSS et al, 2013). Por isso, a Gestão Financeiras e seus fundamentos são cruciais.

Ross et al. (2013) sugere que existem três tipos básicos de questões importantes para o administrador financeiro. A primeira está relacionada aos investimentos de longo prazo, os quais são planejados e gerenciados pelo orçamento de capital, a segunda refere-se a origem e valor dos financiamentos de longo prazo e a forma como será administrado, o que formará a estrutura de capital, ou seja, a combinação entre passivo e patrimônio de uma empresa, por fim, a terceira diz respeito a administração do capital circulante, em outras palavras são as atividades diárias da operação da empresa que abrange as entradas e saídas de caixa.

Além disso, as demonstrações financeiras e o fluxo de caixa são registros muito comuns e importantes para uma efetiva gestão financeira. Através da análise desses é possível compreender a situação financeira e tomar decisões com base em informações concretas.

As demonstrações financeiras, cada uma à sua maneira, relatam a saúde financeira da empresa (ROGERS, 2011). Essas possuem três funções básicas e, de acordo com Bodie e Merton (2002), fornecem:

a) Informações a respeito do desempenho financeiros aos proprietários e credores;

b) Facilidade para definir alvos de desempenho e limitações para a gerência; 
c) Formatos conhecidos para a elaboração do planejamento financeiro.

O balanço patrimonial, composto por ativos, passivos e patrimônio, é um retrato cujo objetivo é mostrar o valor contábil da empresa em um momento específico. A DRE é a demonstração contábil que registra a entrada e saída de recursos da empresa, descrevendo a rentabilidade da mesma em dado exercício. Já a DFC expõe como as atividades operacionais, de investimento e de financiamento alteram o fluxo de caixa, por meio do acompanhamento das fontes e usos de caixas no decorrer de um período (ROGERS, 2011; ROSS et al., 2013).

O fluxo de caixa, também chamado de Lajida ou Ebtida, é a diferença entre as fontes de caixas e usos de caixas. Sua identidade se dá pela equivalência entre o fluxo de caixa dos ativos e a soma do fluxo de caixa para os credores e do fluxo de caixa para os acionistas, ou seja, o fluxo de caixa pago aos fornecedores de capital da empresa (ROSS et al., 2013).

\subsection{Finanças pessoais}

Entende-se Finanças Pessoais como "a ciência que estuda a aplicação de conceitos financeiros nas decisões financeiras de uma pessoa ou família" (CHEROBIN, ESPEJO, 2012, p. 1), assim, a educação financeira é uma combinação de consciência, conhecimento, habilidade, atitude e comportamento que influi em tais decisões, qualificando-as para auferir o bem-estar financeiro (ATKINSON, MESSY, 2012).

Para analisar a possível influência das competências em finanças pessoais, faz-se necessário compreender alguns conceitos relativos a esse assunto. Cebasi (2009) evidencia o orçamento doméstico como relevante para as finanças pessoais, pois ele viabiliza decisões de qualidade por meio do detalhamento dos gastos em determinado período. Cherobin e Espejo (2012) mencionam o planejamento financeiro pessoal, o qual expõe os recursos necessário para alcançar os objetivos e a forma de como obtê-los. 


\subsection{Gestão financeira pessoal}

Segundo Bodie e Merton (2002), há quatro tipos de decisões que são tomadas pelas famílias:

a) Decisões de consumo e economia: destino da renda, podendo ser gasta em consumo ou economizadas para o futuro;

b) Decisões de investimentos: maneira que o dinheiro economizado será investido;

c) Decisões de financiamento: momento e forma como será usado o capital de terceiros para financiar consumos e investimentos;

d) Decisões de administração de risco: situação e meio pelo qual deve-se reduzir ou aumentar os riscos financeiros.

O planejamento financeiro é a base da gestão financeira pessoal e tornase cada vez mais relevante na vida das pessoas, dado que proporciona os meios necessário para alcançar o equilíbrio financeiro. Esse equilíbrio não significa simplesmente estar com as contas em dia, mais do que isso, trata-se de ter reservas financeiras, assim será possível manter-se em casos de imprevistos (CERBASI, 2009).

Dito isto, Cebasi (2009) cita Patrimônio Mínimo de Sobrevivência (PMS), Patrimônio Mínimo Recomendado para sua segurança (PMR), Patrimônio Ideal para sua idade e situação de consumo (PI) e Patrimônio Necessário para a Independência Financeira (PNIF). O primeiro é essencial, pois, com ele será possível se manter quando casos inesperados ocorrerem, como doença, desemprego ou perdas no negócio, "é com essa reserva que você manterá seu padrão de consumo até que as coisas se normalizem" (CERBASI, 2009, p. 15).

Posteriormente, Cebasi (2009) faz menção ao orçamento doméstico, que conforme já mencionado no tópico anterior, descreve com detalhes os gastos, o que viabiliza o equilíbrio orçamentário. Ou seja, por meio dele é possível controlar os gastos e investir com regularidade.

O oposto dessas práticas, resulta no acúmulo de dívidas que muitas vezes saem do controle. Analogamente, como descrito por Cebasi (2009), as dívidas são 
como gorduras no corpo humano, quando não há práticas saudáveis, como o planejamento e orçamento, pode tornar-se excessos nocivos à saúde. Portanto, a "obesidade financeira" precisa ser diagnosticada e tratada o quanto antes.

Para reverter esse quadro e construir os patrimônios mencionados, é importante também a compreensão do conceito de investimento, isto é, o comprometimento de recursos a fim de obter retorno no futuro (BODIE, KANE, MARCUS, 2014), ou melhor, "multiplicar suas reservas financeiras" (CERBASI, 2009, p. 90). 


\section{Metodologia}

\subsection{Método de pesquisa utilizado}

A pesquisa classifica-se como exploratória e descritiva, quanto aos objetivos, dado que o estudo visa verificar a existência de relação entre duas variáveis, trata-se das variáveis competências em finanças pessoais e capacidade de gestão financeira (GIL, 2002). Em relação aos procedimentos técnicos, referese à um levantamento, tendo em vista que o estudo se deu por meio da solicitação de informações à um grupo de pessoas a fim de conhecer seu comportamento e analisar o problema estudado de forma quantitativa (GIL, 2002).

\subsection{Fontes de informação selecionadas para coleta de dados no estudo}

Os dados da pesquisa foram fornecido por pessoas por meio de questionário. O tamanho da amostra é de 96 microempreendedores cujos negócios estão localizados na região metropolitana do Rio de Janeiro e possuem mais de dois anos de funcionamento sob a mesma gestão. Tal amostra é subconjunto de uma população de empreendedores donos de microempresas na região metropolitana do Rio de Janeiro, logo, a amostragem é não-probabilística, sem rigor estatístico, de acordo com a disponibilidade dos entrevistados.

\subsection{Procedimentos e instrumentos de coleta de dados utilizados no estudo}

O instrumento de coleta foi um questionário padronizado utilizando-se de indagação direta com questões fechadas, realizadas de forma individual, tendo sido presencial ou virtual por meio do software de pesquisas online Qualtrics. O questionário possui 26 perguntas e está dividido em três sessões, a primeira parte solicita informações demográficas sobre o entrevistado e sua empresa, depois são 
perguntas sobre a gestão financeira da microempresa e, por fim, perguntas semelhantes às anteriores, porém em relação às finanças pessoais do microempreendedor.

\subsection{Formas de tratamento e análise dos dados coletados para o estudo}

Fundamentado no critério utilizado para a análise de dados, a abordagem da pesquisa é quantitativa cujo objetivo é encontrar uma relação mensurável entre as variáveis estudadas. Os dados serão apresentados em forma de percentual para identificar as respostas mais recorrentes e, assim, identificar as decisões financeiras mais comuns.

A fim de encontrar relação entre a gestão financeira pessoal e a gestão financeira da microempresa, algumas questões da seção de gestão financeira do negócio são semelhantes às da seção de gestão financeira pessoal, formando pares que possibilitam a comparação. Desse modo, será utilizada tabulação cruzada com o intuito de analisar a associação entre variáveis qualitativas.

\subsection{Limitações da pesquisa}

A pesquisa foi direcionada aos donos de microempresas, ou seja, negócios com faturamento bruto anual de até $\mathrm{R} \$ 360.000,00$, sem restrições para negócios informais. Desse modo, a pesquisa pôde ser respondidas por donos de empresas que não possuem CNPJ. Por não serem formalmente reconhecidos pelo governo e órgãos reguladores, muito negócios não possuem dívidas e investimentos e, então, mesmo que os donos quisessem não poderiam tê-los. Portanto, essa pode ser considerada a maior limitação do estudo, já que impossibilita muitos donos de tomar tais iniciativas pelo negócio e os levam a tomá-las apenas no âmbito das finanças pessoais.

Outra limitação relevante é o fato de não ser possível medir de maneira precisa a relação entre as competência em finanças pessoais e a gestão financeira do negócio, visto que existem inúmeros fatores que influenciam esta última. Além disso, há também a utilização de uma amostra pequena comparada à população 
total, que gera um baixo nível de confiança nos resultados, e a delimitação geográfica restrita à região metropolitana do Rio de Janeiro, que torna a pesquisa enviesada para as especificidades da região. 


\section{Apresentação e análise dos resultados}

Sobre o perfil dos microempreendedores entrevistados, é sabido que $62,5 \%$ possuem mais de 44 anos e 66,7\% pertencem ao sexo masculino. Quanto ao nível de escolaridade, $20,9 \%$ dos entrevistados não possuem o ensino médio completo e $56,3 \%$ não possuem nível superior completo. A maioria $(91,7 \%)$ possui uma renda mensal superior a dois salários mínimos, sendo $52,1 \%$ mais do que cinco salários mínimos.

Descobriu-se que 47,9\% dos respondentes já tiveram outros negócios, entre eles, $65,2 \%$ assinalaram a alternativa "outros" como razão de ter fechado, no qual parte significativa mencionou problemas com sócios como causa para 0 fechamento do negócio. Apesar disso, os respondentes também apontaram a falha na gestão $(21,7 \%)$ e a falha no planejamento $(17,4 \%)$, o que pode estar associado à falta de capacitação em gestão empresarial, mesmo que apenas $4,3 \%$ tenha mencionado a mesma.

De todos os microempreendedores entrevistados, $85,4 \%$ declararam ser eles ou os sócios os responsáveis pela gestão financeira do negócio, desse modo, percebe-se a importância da qualificação dos donos do negócio em gestão financeira. A principal forma pela qual se qualificaram para fazer a gestão do negócio foi a experiência profissional, tendo sido selecionada por $66,7 \%$ dos respondentes e se destacado em relação às formas de qualificação formais, como cursos de treinamento, cursos técnicos, graduação, pós-graduação, o que pode ser um problema, já que a gestão é feita sem conhecimento teórico apropriado.

Quando questionado aos microempreendedores se eles separam as contas da empresa de suas contas pessoais, 66,7\% afirmaram separar, 31,3\% afirmaram não separar e 2,1\% disseram que às vezes separam. Apesar da maioria das pessoas terem afirmado que separam as contas da empresa de suas contas pessoais, há um percentual significativo que não o fazem, o que mostra a presença da informalidade nas microempresas. 
A fim de encontrar relação entre a gestão financeira pessoal e a gestão financeira do negócio, algumas questões de tais seções no questionário são semelhantes e formam pares que possibilitam a comparação, variando apenas as alternativas de acordo com a especificidade de cada área.

Em relação ao quanto os microempreendedores se consideram qualificados para fazer a gestão financeira do seu negócio, a maioria dos entrevistados afirmaram ser "suficientemente qualificado" (45,8\%) ou "insuficientemente qualificado" (31,3\%). Já no que diz respeito ao quanto os respondentes se consideram qualificados para fazer uma boa gestão das finanças pessoais, a maioria se consideraram "suficientemente qualificado" $(64,6 \%)$.

Conforme mostra o gráfico 2, todas as pessoas que afirmaram não ser qualificadas para fazer uma boa gestão de suas finanças pessoais, consideram também não ser qualificadas $(33,3 \%)$ ou ser insuficientemente qualificadas $(66,7 \%)$ para fazer a gestão financeira do seu negócio. Entre as pessoas que afirmaram ser insuficientemente qualificadas para fazer uma boa gestão financeira pessoal, 62,5\% também se consideram insuficientemente qualificadas para fazer a gestão financeira do seu negócio e o restante se distribui igualmente entre as outras alternativas.

Já as pessoas que se consideram suficientemente qualificadas para fazer uma boa gestão de suas finanças pessoais, $71 \%$ se consideram suficientemente qualificadas $(58,1 \%)$ ou muito qualificadas $(12,9 \%)$ para fazer a gestão financeira do seu negócio. Entre os que se consideram muito qualificados para fazer a gestão de suas finanças pessoais, $50 \%$ se consideram suficientemente qualificados e os outros $50 \%$ se consideram muito qualificados para fazer a gestão financeira do seu negócio.

A partir dos resultados, nota-se que a maioria das pessoas ou apresentam uma percepção negativa em relação à sua qualificação para gerenciar tanto as finanças pessoais quanto as finanças do negócio ou acreditam ter qualificação para gerenciar todas as finanças de um modo geral. 


\section{Percepção sobre o nível de qualificação}

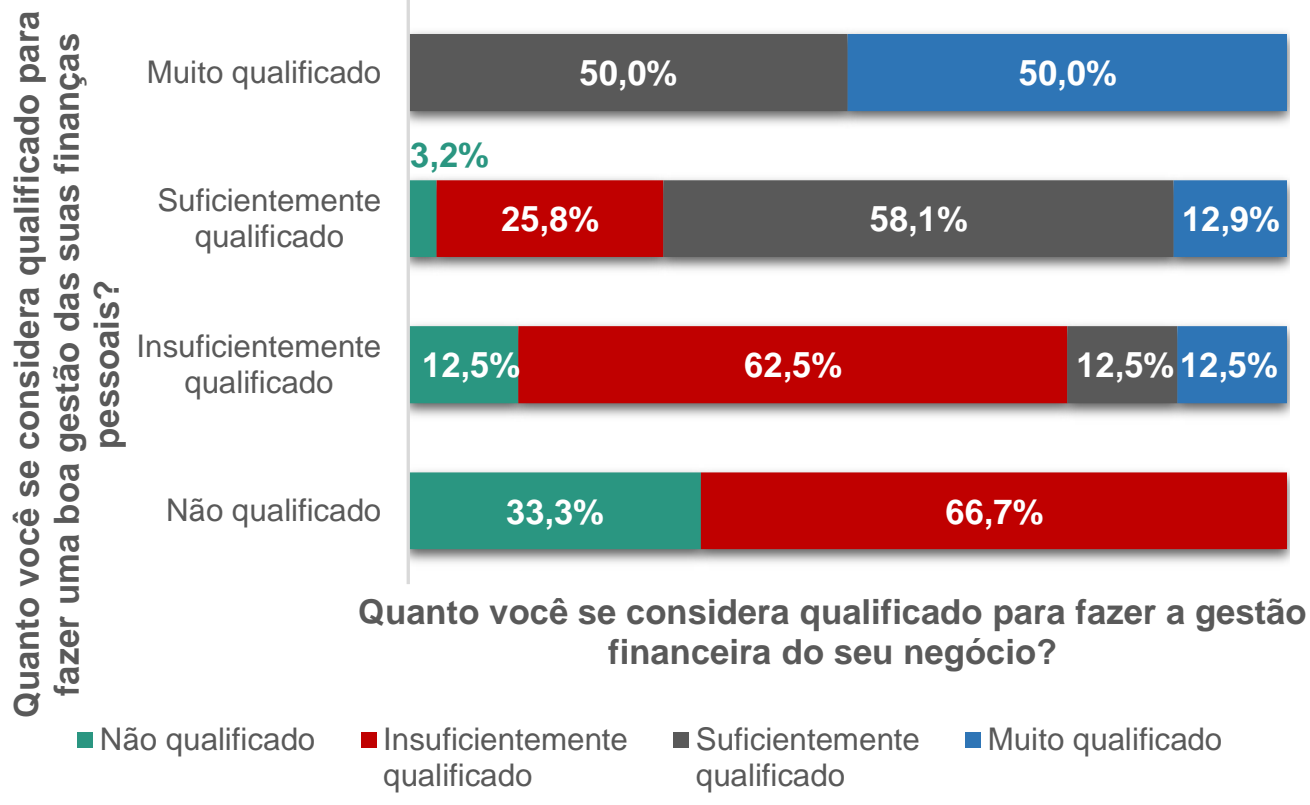

Gráfico 2 - Percepção sobre o nível de qualificação Fonte: Elaborado pela autora

Os microempreendedores entrevistados que utilizam as demonstrações financeiras para gerenciar o negócio representam $29,2 \%$. Os outros $70,8 \%$ não utilizam, desses, 47,9\% possuem demonstrações financeiras apenas para atender as obrigações legais e $22,9 \%$ não possuem demonstrações financeiras. A partir desse último dado é possível notar mais uma vez falta de conhecimento teórico e a informalidade dos negócios. No que diz respeito às finanças pessoais, apenas $50 \%$ dos entrevistados afirmaram possuir algum tipo de planejamento pessoal.

É possível notar no gráfico 3 , que entre os respondentes que não fazem planejamento financeiro pessoal, a proporção que afirmou não ter as demonstrações financeiras do negócio utilizadas é maior $(83,3 \%)$ quando comparada aos entrevistados que fazem o planejamento financeiro $(58,3 \%)$. 


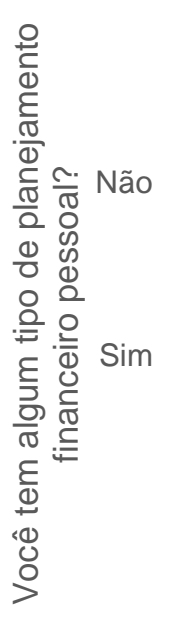

\section{Planejamento financeiro pessoal e demonstrações financeiras}

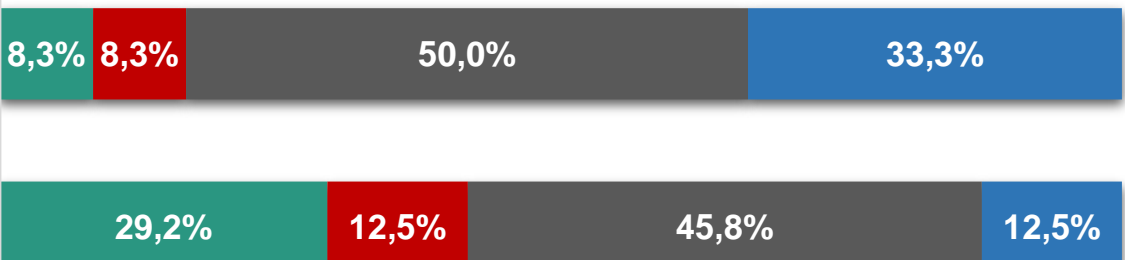

As demonstrações financeiras são utilizadas para gerenciar o negócio?

- Sim, eu utilizo

- Sim, outra pessoa utiliza

- Não, apenas atendem as obrigações legais

- Não, a empresa não possui demonstrações financeiras

Gráfico 3 - Planejamento financeiro pessoal e demonstrações financeiras Fonte: Elaborado pela autora

Sobre as dívidas do negócio, 45,8\% das pessoas afirmaram que suas microempresas não possuem dívidas, $27,1 \%$ possuem um nível baixo de endividamento, 16,7\% possuem um nível ótimo de endividamento e 10,4\% possuem nível alto de endividamento. Sendo as principais fontes de endividamento das microempresas: fornecedores $(84,6 \%)$, cartão de crédito $(26,9 \%)$ e empréstimo $(26,9 \%)$.

Já no que diz respeito às dívidas pessoais, 45,8\% das pessoas afirmaram não possuir dívidas pessoais, $27,1 \%$ possuem dívidas que representam mais de $20 \%$ da sua renda e $22,9 \%$ possuem dívidas que representam até $20 \%$ da sua renda. Ademais, suas principais fontes de endividamento são: cartão de crédito $(76,9 \%)$, financiamento $(38,5 \%)$, empréstimo $(23,1 \%)$ e cheque especial $(23,1 \%)$.

De acordo com o gráfico 4, dos respondentes que não possuem dívidas pessoais, 59,1\% também não possuem empresas com dívidas, além disso, 18,2\% possuem um nível de endividamento baixo e 18,2\% possuem um nível de endividamento ótimo. Há também os respondentes que possuem dívidas de até $20 \%$ da sua renda, entre eles $27,3 \%$ possuem negócio sem dívida e 45,5\% possuem negócios com nível baixo de endividamento. Das pessoas que declararam possuir dívidas que representam mais que $20 \%$ da sua renda, $46,2 \%$ 
responderam que suas empresas não possuem dívidas e 30,8\% que possuem um nível baixo de endividamento.

Desse modo, a pesquisa apontou que entre os respondentes que não possuem dívidas pessoais, a maioria também não possui empresas com dívidas, além disso, uma parte significativa têm dívidas abaixo da média tanto pessoal quanto na empresa. Como uma minoria de pessoas afirmaram possuir negócios com alto nível de endividamento, eles não estão evidentes, porém os relatos de negócios com alto nível de endividamento é constatado, em sua maioria (80\%), partindo das pessoas que afirmaram ter dívidas pessoais.

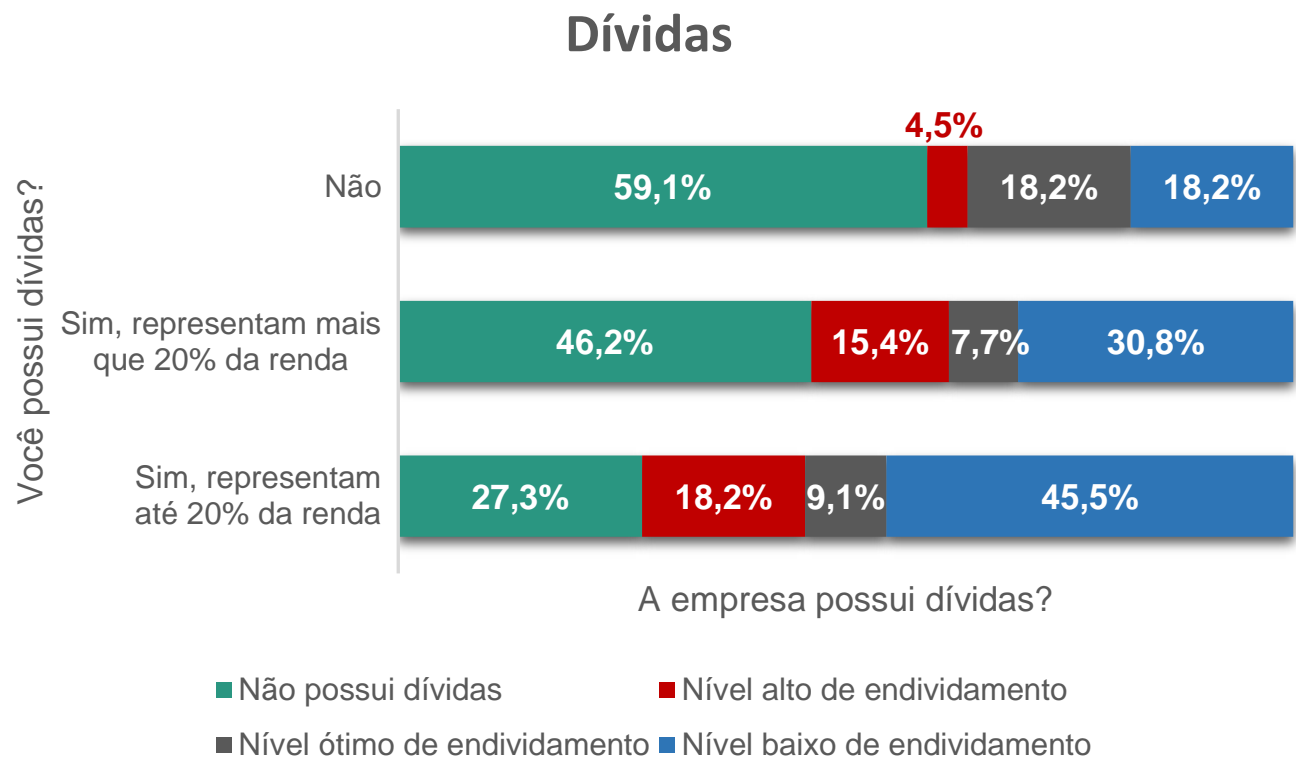

Gráfico 4 - Dívidas

Fonte: Elaborado pela autora

Em relação aos negócios com dívidas, 30,8\% dos respondentes afirmaram que os mesmos também possuem dívidas em atraso. Já entre os microempreendedores entrevistados detentores de dívidas pessoais, 34,6\% também possuem dívidas em atraso.

Conforme o gráfico 5, das pessoas que não possuem dívidas pessoais em atraso, $66,7 \%$ delas também não possuem negócios com dívidas em atraso. Por outro lado, das pessoas que possuem dívidas em atraso, $60 \%$ também possuem pela empresa. Desse modo, a maioria dos inadimplentes têm negócios 
inadimplentes, assim como a maioria dos adimplentes possuem negócios adimplentes.

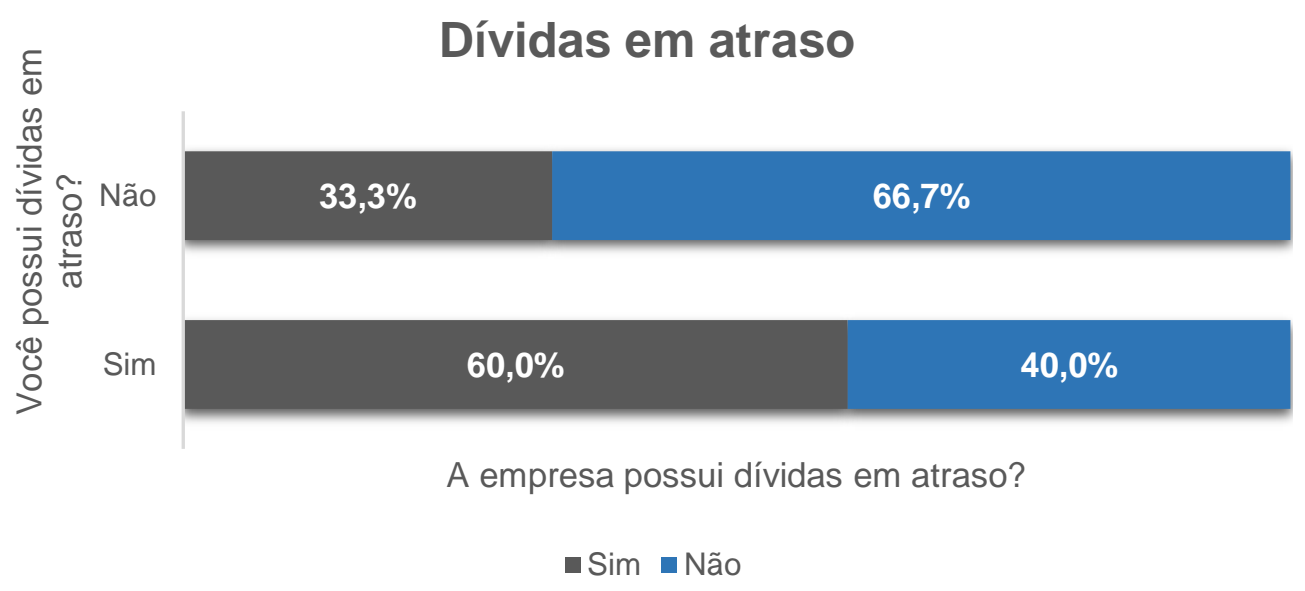

Gráfico 5 - Dívidas em atraso

Fonte: Elaborado pela autora

Referente aos investimentos, 68,8\% das pessoas afirmaram que seu negócio não possui qualquer tipo de investimento financeiro, 18,8\% afirmaram que possui investimentos em poupança e 10,4\% em fundos de investimento, sendo os mais selecionados entre os respondentes. Já em relação aos investimentos financeiros pessoais dos entrevistados, 33,3\% das pessoas afirmaram não possuir qualquer tipo de investimento financeiro pessoal, 41,7\% das pessoas possuem investimentos em poupança, $25 \%$ em previdência privada e $18,8 \%$ em fundos de investimentos, esses são os principais investimentos dos entrevistados. Dessa forma, observa-se mais um vez a preferência do brasileiro pela poupança e percebe-se que é mais comum ter investimentos pessoais do que no negócio, o que talvez possa ser explicado pela informalidade ou até mesmo pela falta de qualificação dos empreendedores.

Como a maioria dos microempreendedores entrevistados não possuem investimentos financeiros ou investem em poupança, a comparação é com base nessas opções e está apresentada no gráfico 6. De todas as pessoas que afirmaram não possuir investimento financeiro pessoal, $75 \%$ também não possuem investimento financeiro pelo negócio e $25 \%$ selecionaram que possuem outros investimentos, diferentes dos listados nas alternativas da questão. Entre as pessoas que possuem investimento pessoal em poupança, 40\% afirmaram também possuir investimento em poupança pelo negócio, 55\% afirmaram que seu 
negócio não possui investimento financeiro e 5\% afirmaram que o negócio possui fundos de investimento.

Portanto, de todas as pessoas que afirmaram não possuir investimento financeiro pessoal, a maioria também não possui investimento financeiro pela microempresa e entre as pessoas que possuem investimento pessoal em poupança, parte afirmou também possuir investimento em poupança pelo negócio e a maioria afirmou que seu negócio não possui investimento financeiro.

\section{Investimentos financeiros}
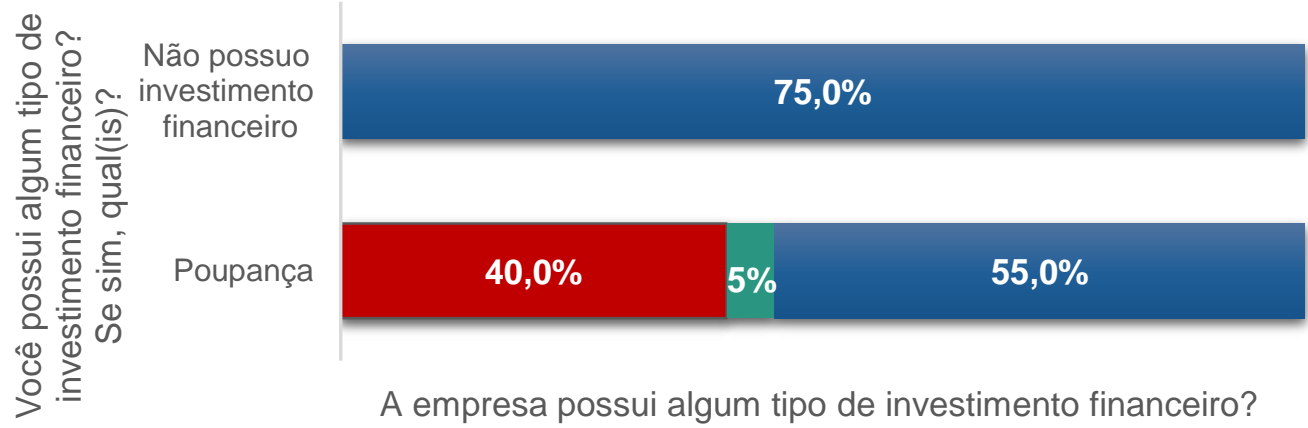

A empresa possui algum tipo de investimento financeiro? Se sim, qual(is)?

घoupança - Fundos de investimento Não possui investimento financeiro

Gráfico 6 - Investimentos financeiros

Fonte: Elaborado pela autora

Quando questionada a finalidade dos investimentos para aqueles que possuem algum tipo de investimento financeiro pelas microempresas, $80 \%$ afirmaram ser para reserva de emergência, 40\% afirmaram ser uma poupança para efetuar melhorias e/ou ampliações no negócio e 13,3\% declararam que o objetivo é rentabilizar o caixa da empresa. Quanto a finalidade dos investimentos financeiros pessoais, 71,9\% responderam ser uma reserva de emergência, 40,6\% ser um plano de aposentadoria, 25\% afirmaram investir para receber rendimentos e $12,5 \%$ afirmaram ser uma poupança para aquisição de algum bem de alto valor.

O gráfico 7 mostra que, de todos os microempreendedores entrevistados possuidores de investimentos financeiros para receber rendimentos, 100\% afirmaram ter investimentos financeiros no negócio para rentabilizar o caixa da empresa, 50\% disseram ser para reserva de emergência e 50\% selecionaram "outros". Dos que possuem investimentos financeiros pessoais a fim de poupar 
para aquisição de algum bem de alto valor, $66,7 \%$ afirmaram que os investimentos financeiros do negócio são uma reserva de emergência, 50\% selecionaram "outros", 33,3\% declararam ser para rentabilizar o caixa da empresa e 33,3\% ser uma poupança para efetuar melhorias e/ou ampliações do negócio. Já as pessoas que afirmaram que seus investimentos financeiros pessoais são uma reserva de emergência, $75 \%$ também afirmaram ter essa mesma finalidade para os investimentos financeiros do negócio, enquanto 25\% afirmaram ser para rentabilizar o caixa da empresa e $25 \%$ ser poupança para efetuar melhorias e/ou ampliações do negócio.

Sendo assim, vale ressaltar que, dos entrevistados que disseram ter investimentos financeiros pessoais como uma reserva de emergência, a maioria afirmou ter essa mesma finalidade para os investimentos financeiros do negócio. Dos respondentes que possuem investimentos financeiros para receber rendimentos, todos afirmaram ter investimentos financeiros no negócio para rentabilizar o caixa da empresa.

\section{Finalidade dos investimentos financeiros}

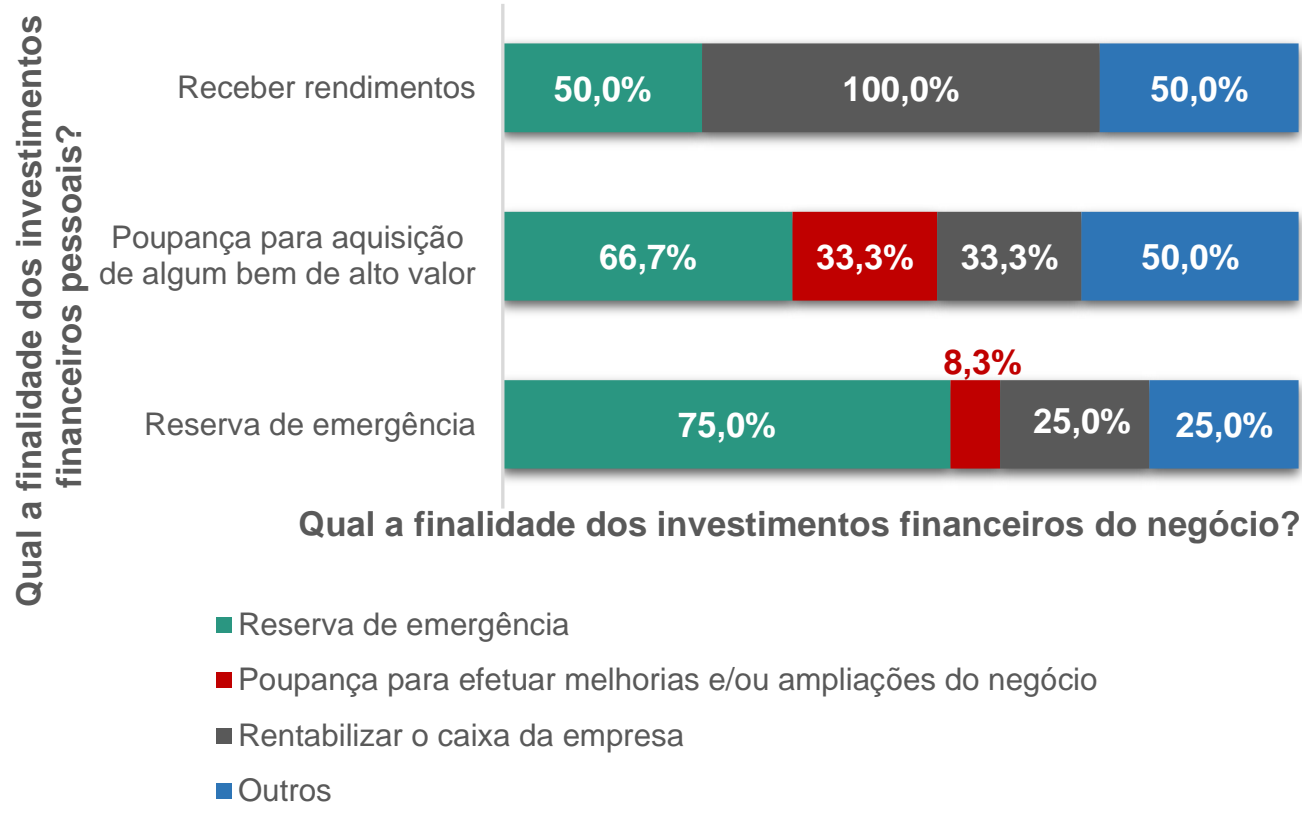

Gráfico 7 - Finalidade dos investimentos financeiros Fonte: Elaborado pela autora 
Conclui-se que é possível observar a relação entre o padrão de decisões na gestão das finanças pessoais do microempreendedor e na gestão financeira da microempresa, tendo em vista que a situação financeira e a forma como o microempreendedor faz a gestão de ambos é semelhante. Ainda que não seja uma relação forte a ponto de afirmar que as variáveis são dependentes, já que há diversas outras coisas que envolvem o universo dos negócios, as decisões relativas às finanças pessoais têm influência sobre as decisões financeiras da microempresa, desse modo, a falta de competência para gerenciar as finanças pessoais pode acarretar em decisões financeiras ruins para o negócio. 


\section{Conclusões}

O estudo teve como objetivo analisar a influência das competências em finanças pessoais do microempreendedor na gestão financeira de uma microempresa. Para tal, foi feita uma pesquisa em finanças pessoais de microempreendedores e gestão financeira de microempresas cujo método utilizado foi uma pesquisa descritiva feita por meio de um levantamento, no qual coletou informações de 96 donos de microempresas localizadas na região metropolitana do Rio de Janeiro e em funcionamento há mais de 2 anos.

Observou-se que há relação entre a gestão financeira pessoal e a gestão financeira das microempresas, mesmo que não seja uma relação forte, a falta de competência na gestão das finanças pessoais pode gerar decisões financeiras ruins para o negócio.

Como visto, com base na aderência de dívidas, dívidas em atraso e investimentos por parte dos microempreendedores, as decisões financeiras dos negócios são semelhantes às decisões financeiras pessoais dos donos de microempresas, consequentemente, as situações financeiras de ambos também não são muito diferentes. A maioria dos negócios têm dívidas, mas não possuem dívidas em atraso e investimentos financeiros, bem como, a maioria dos microempreendedores têm dívidas pessoais, mas não dívidas em atraso e possuem investimentos em poupança.

Apesar da maioria dos microempreendedores fazerem a gestão financeira do negócio por conta própria, a maior parte não se qualificou para tal. Ademais, as demonstrações financeiras não são utilizadas pela maioria dos microempreendedores e o planejamento financeiro pessoal é feito apenas pela metade.

Portanto, os achados são relevantes para evidenciar mais uma vez a importância da educação financeira e considerar a possibilidade de investir nela antes de investir em um negócio. Estudos futuros poderão verificar essa relação 
de forma mais abrangente, no sentido de atingir um número maior de pessoas e de regiões, bem como, ao ser mais especifico na coleta de informações sobre as finanças pessoais e as finanças das microempresas e, dessa forma, medir o impacto que a competência em finanças pessoais, ou a falta dela, tem na sobrevivência dos negócios. 


\section{Referências Bibliográficas}

ATKINSON, A.; MESSY, F. Measuring Financial Literacy: Results of the OECD / International Network on Financial Edcation (INFE) Pilot Study, OECD Working Papers on Finance, Insurance and Private Pensions. 15. ed. Paris, 2012. 73 p. Disponível em: <https://www.oecd-ilibrary.org/docserver/5k9csfs90fr4en.pdf?expires $=1552589000 \&$ id=id\&accname=guest $\&$ checksum $=1$ B3B70430F27 54F548FCDD7C69F77C43>.

BANCO CENTRAL DO BRASIL. Série temporal: Comprometimento de renda das famílias com o serviço da dívida com o Sistema Financeiro Nacional - Com ajuste sazonal. Disponível em: <https://www3.bcb.gov.br/sgspub/consultarvalores/consultarValoresSeries.do?m ethod=getPagina $>$. Acesso em: 5 mai. 2019.

BANCO CENTRAL DO BRASIL. Série Cidadania Financeira: Estudos sobre Educação, Proteção e Inclusão, 2017. 76 p. Disponível em: $<$ https://www.bcb.gov.br/nor/relincfin/serie_cidadania_financeira_pesquisa_infe_ br_\%200443_2017.pdf>. Acesso em: 14 mar. 2019.

BODIE, Zvi; KANE, Alex; MARCUS, Alan. Fundamentos de Investimentos. 9. ed.: AMGH, 2014.

BODIE, Zvi; MERTON, Robert C. Finanças. 1. ed. Porto Alegre: Bookman, 2002. BRASIL. LEI COMPLEMENTAR № 123. 14 DE DEZEMBRO DE 2006, 14 DE DEZEMBRO DE 2006. Disponível em: <http://www.planalto.gov.br/CCivil_03/leis/LCP/Lcp123.htm>. Acesso em: 17 out. 2018.

CERBASI, Gustavo. Como organizar sua vida financeira: Inteligência financeira pessoal na prática. Rio de Janeiro: Elsevier; Campus, 2009. 107 p.

CHEROBIN, Ana Paula; ESPEJO, Márcia. Finanças Pessoais: Conhecer para enriquecer! 2. ed. São Paulo: Atlas, 2012. 19 p. 
DOLABELA, Fernando. Oficina do Empreendedor: A metodologia de ensino que ajuda a transformar conhecimento em riqueza. 1. ed. Rio de Janeiro: Sextante, 2008. 36 p.

GIL, Antonio Carlos. Como elaborar projetos de pesquisa. 4. ed. São Paulo: Atlas S.A., 2002.

GLOBAL ENTREPRENEURSHIP MONITOR. Empreendedorismo no Brasil: Relatório Executivo 2013, 2013. 20 p. Disponível em: <http://www.sebrae.com.br/Sebrae/Portal\%20Sebrae/Anexos/Relatorio\%20Exec utivo\%20GEM\%202013.pdf>. Acesso em: 14 mar. 2019.

GLOBAL ENTREPRENEURSHIP MONITOR. Empreendedorismo no Brasil: Relatório Executivo 2016, 2016. 210 p. Disponível em: <http://www.sebrae.com.br/Sebrae/Portal\%20Sebrae/Anexos/GEM\%20Nacional \%20-\%20web.pdf>. Acesso em: 14 mar. 2019.

GLOBAL ENTREPRENEURSHIP MONITOR. Empreendedorismo no Brasil: Relatório Executivo 2017, 2017. 23 p. Disponível em: <http://www.sebrae.com.br/Sebrae/Portal\%20Sebrae/Anexos/Relat\%C3\%B3rio\% 20Executivo\%20BRASIL_web.pdf>. Acesso em: 14 mar. 2019.

INSTITUTO BRASILEIRO DE GEOGRAFIA E ESTATÍSTICA. As micro e pequenas empresas comerciais e de serviços no Brasil. Rio de Janeiro, 2003. 100 p. Disponível em: <https://biblioteca.ibge.gov.br/visualizacao/livros/liv1898.pdf>. Acesso em: 14 mar. 2019.

OCDE/INFE. Internacional Survey of Adult Financial Literacy Competencies, 2016. 100 p. Disponível em: <http://www.oecd.org/daf/fin/financialeducation/OECD-Infe-International-Survey-of-Adult-FInancial-LiteracyCompetencies.pdf>. Acesso em: 12 mar. 2019.

ROGERS, Steven. Finanças e Estratégias de Negócios para Empreendedores. 2. ed. Porto Alegre: Bookman, 2011.

ROSS, Stephen A.; WESTERFIELD, Randolph W.; JORDAN, Bradford D.; LAMB, Roberto. Fundamentos de administração financeira. 9. ed. Porto Alegre: AMGH, 2013. 782 p. ISBN 9788580552249. 
SERVIÇO BRASILEIRO DE APOIO ÀS MICRO E PEQUENAS EMPRESAS. Os donos de negócio no Brasil: Análise por faixa de escolaridade (2003-2013), 2015. $36 \quad$ p. $\quad$ Disponível em: <https://bibliotecas.sebrae.com.br/chronus/ARQUIVOS_CHRONUS/bds/bds.nsf/ d3c0e8820c57aec918b46d14475ccaec/\$File/5770.pdf>. Acesso em: 14 mar. 2019.

SERVIÇO BRASILEIRO DE APOIO ÀS MICRO E PEQUENAS EMPRESAS. Sobrevivência das empresas no Brasil. Brasília, 2016. 100 p. Disponível em: <https://m.sebrae.com.br/Sebrae/Portal\%20Sebrae/Anexos/sobrevivencia-dasempresas-no-brasil-102016.pdf>. Acesso em: 14 mar. 2019.

SPC BRASIL; CNDL. Endividamento e impactos nas finanças do consumidor, 2018. 9 p. Disponível em: <https://www.spcbrasil.org.br/wpimprensa/wpcontent/uploads/2018/02/An\%C3\%A1 lise-Endividamento-e-Impactos-nasFinancas-do-Consumidor.pdf>. Acesso em: 29 abr. 2019. 


\section{Anexos}

\section{Anexo 1 - Questionário da pesquisa}

Pesquisa em finanças pessoais de microempreendedores e gestão financeira de microempresas

Gostaria da sua colaboração para a realização dessa pesquisa para o meu trabalho de conclusão de curso. O objetivo é analisar a influência das competências em finanças pessoais do empreendedor na gestão financeira de microempresas.

Para respondê-la é necessário que você seja dono de microempresa, ou seja, negócios que faturam entre $R \$ 81.000,00$ e $R \$ 360.000,00$ ao ano, seja localizada na região metropolitana do Rio de Janeiro e esteja em funcionamento há 2 anos ou mais.

O questionário divide-se em 3 sessões e dura entre 5 a 10 minutos. As respostas serão tratadas de forma sigilosa, não identificando os respondentes.

\section{Seção 1 - Informações Pessoais}

Q1 Qual a sua faixa etária?

- Até 34 anos

o $\quad 35$ a 44 anos

o $\quad 44$ a 64 anos

o $\quad 65$ anos ou mais

Q2 Qual seu sexo?

o Masculino

o Feminino

o $\quad$ Prefiro não dizer 
Q3 Qual seu nível de escolaridade?

o Ensino Fundamental Incompleto

- Ensino Fundamental Completo

o Ensino Médio Incompleto

- Ensino Médio Completo

- Ensino Superior Incompleto

- Ensino Superior Completo

Q4 Qual sua renda mensal?

- Até 2 salários mínimos

- $\quad$ Entre 2 e 5 salários mínimos

- Mais de 5 salários mínimos

Q5 Qual o ano de criação da empresa?

Q6 Qual o segmento do seu negócio?

Q7 Já teve outros negócios?

o Sim

○ Não 
Q8 Por que fechou? Selecione todas que se aplicam.

Situação desfavorável antes da abertura

Falha no planejamento do negócio

Falha na gestão do negócio

Falta de capacitação em gestão empresarial

Outros:

\section{Seção 2 - Gestão Financeira do Negócio}

Q9 Você separa as contas da empresa de suas contas pessoais?
o $\quad \operatorname{Sim}$
○ Não
$0 \quad$ Às vezes

Q10 Quem faz a gestão financeira do negócio?

- Eu/sócio

- $\quad$ Colaborador com qualificação em gestão financeira

- Colaborador sem qualificação em gestão financeira

Q11 Quanto você se considera qualificado para fazer a gestão financeira do seu negócio?
○ Não qualificado
- Insuficientemente qualificado
- Suficientemente qualificado
○ Muito qualificado 
Q12 Como se qualificou para fazer a gestão do negócio? Selecione todas que se aplicam.
Curso de treinamento
$\square \quad$ Curso técnico
- Graduação
口 Pós-graduação
$\square \quad$ Experiência profissional
$\square \quad$ Não me qualifiquei
$\square$ Outro:

Entende-se por demonstrações financeiras: relatórios contábeis que apresentam a saúde financeira da empresa, inclui DRE, DFC, Balanço patrimonial, entre outros.

Q13 As demonstrações financeiras são utilizadas para gerenciar o negócio?
o Sim, eu utilizo
- S Sim, outra pessoa utiliza
- Não, apenas atendem as obrigações legais
- Não, a empresa não possui demonstrações financeiras

Entende-se por dívida: prestações a vencer e empréstimos a pagar.

\section{Q14 A empresa possui dívidas?}
- Sim, a empresa possui nível alto de endividamento
- S Sim, a empresa possui nível ótimo de endividamento
- Sim, a empresa possui nível baixo de endividamento
- Não possui dívidas 
Q15 Qual(is) tipo(s) de dívidas? Selecione todas que se aplicam.

- Financiamento

- Empréstimo

$\square \quad$ Fornecedores

Cartão de crédito

Conta garantida (cheque especial)

Impostos

Outro:

Q16 A empresa possui dívidas em atraso?

0 Sim

○ Não

Entende-se por investimento: comprometimento de recursos a fim de obter retorno no futuro.

Q17 A empresa possui algum tipo de investimento financeiro? Se sim, qual(is)? Selecione todas que se aplicam.

○ Poupança

$\square \quad$ Títulos públicos

$\square \quad$ Fundos de investimento

$\square \quad$ Ações

CDB/RDB

LCI/LCA

Não possui investimento financeiro

Outro:

Q18 Qual sua finalidade? Selecione todas que se aplicam.

Reserva de emergência

- Poupança para efetuar melhorias/ampliação do negócio

$\square \quad$ Rentabilizar o caixa da empresa

Outro: 


\section{Seção 3 - Gestão Financeira Pessoal}

Entende-se por planejamento financeiro pessoal: definição dos recursos necessário para alcançar os objetivos e a forma de como obtê-los.

Q19 Você tem algum tipo de planejamento financeiro pessoal?

$\begin{array}{ll}0 & \text { Sim } \\ 0 & \text { Não }\end{array}$

Q20 Como você o faz?

- Orçamento doméstico em planilha

- Anotações em um caderno

- Software de controle financeiro

o Outro:

Q21 Quanto você se considera qualificado para fazer uma boa gestão das suas finanças pessoais?
○ Não qualificado
- Insuficientemente qualificado
- Suficientemente qualificado
- Muito qualificado

Entende-se por dívida: prestações a vencer e empréstimos a pagar.

Q22 Você possui dívidas?
- Sim, tenho dívidas e representam até $20 \%$ da minha renda
- Sim, tenho dívidas e representam mais que $20 \%$ da minha renda
- S Sim, tenho dívidas e não sei dizer quanto é
○ Não tenho 
Q23 Qual(is) tipo(s) de dívidas? Selecione todas que se aplicam.

$\square \quad$ Financiamento

口 Empréstimo

$\square \quad$ Crédito consignado

- Carnê de lojas

Cartão de crédito

Cheque especial

Outro:

Q24 Você possui dívidas em atraso?

o Sim

○ Não

Entende-se por investimento: comprometimento de recursos a fim de obter retorno no futuro.

Q25 Você possui algum tipo de investimento financeiro? Se sim, qual(is)? Selecione todas que se aplicam.

Poupança

Previdência Privada

$\square \quad$ Títulos públicos

$\square \quad$ Fundos de investimento

Ações

$\square \quad \mathrm{CDB} / \mathrm{RDB}$

LCl/LCA

Não possuo investimento financeiro

$\square$ Outro: 
Q26 Qual sua finalidade? Selecione todas que se aplicam.

$\square \quad$ Reserva de emergência

$\square$ Poupança para aquisição de algum bem de alto valor

$\square \quad$ Receber rendimentos

$\square \quad$ Plano de aposentadoria

$\square \quad$ Outro: 


\section{Anexo 2 - Gráficos com resultados da pesquisa}

\section{Qual a sua faixa etária?}

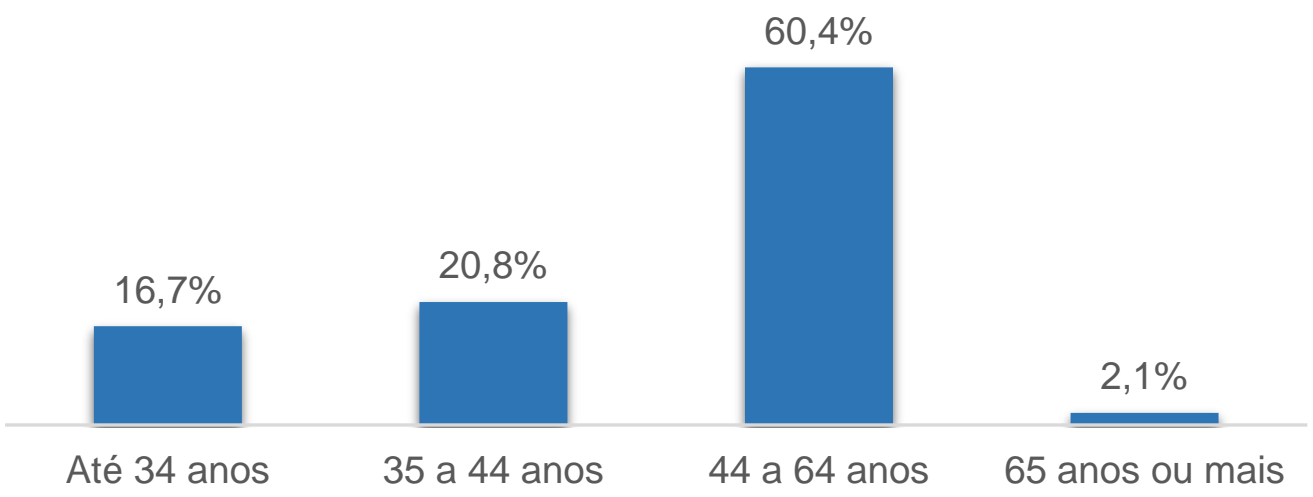

Gráfico 8-Qual a sua faixa etária?

Fonte: Elaborado pela autora

\section{Qual seu sexo?}

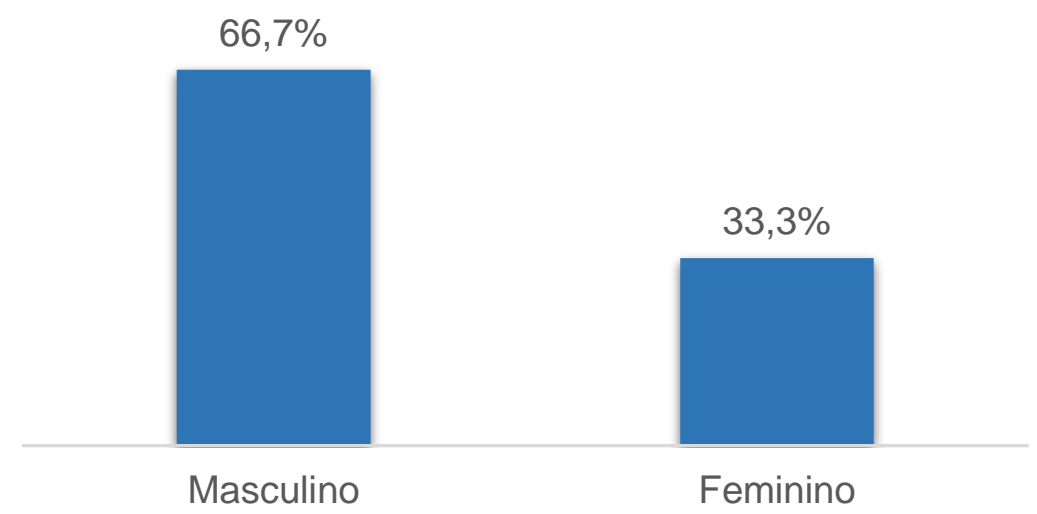

Gráfico 9 - Qual seu sexo?

Fonte: Elaborado pela autora 


\section{Qual sua renda mensal?}

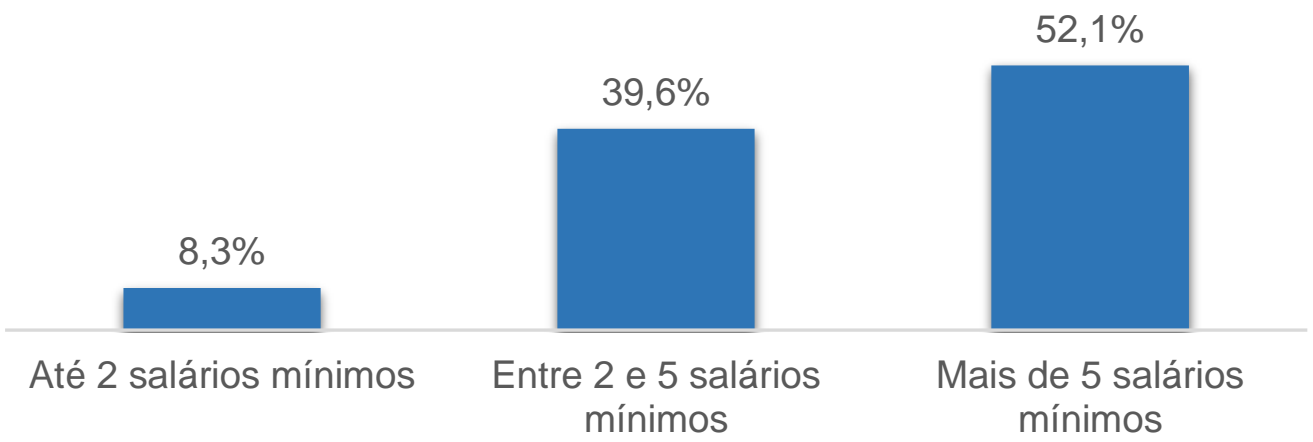

Gráfico 10 - Qual a sua renda mensal?

Fonte: Elaborado pela autora

\section{Qual seu nível de escolaridade?}

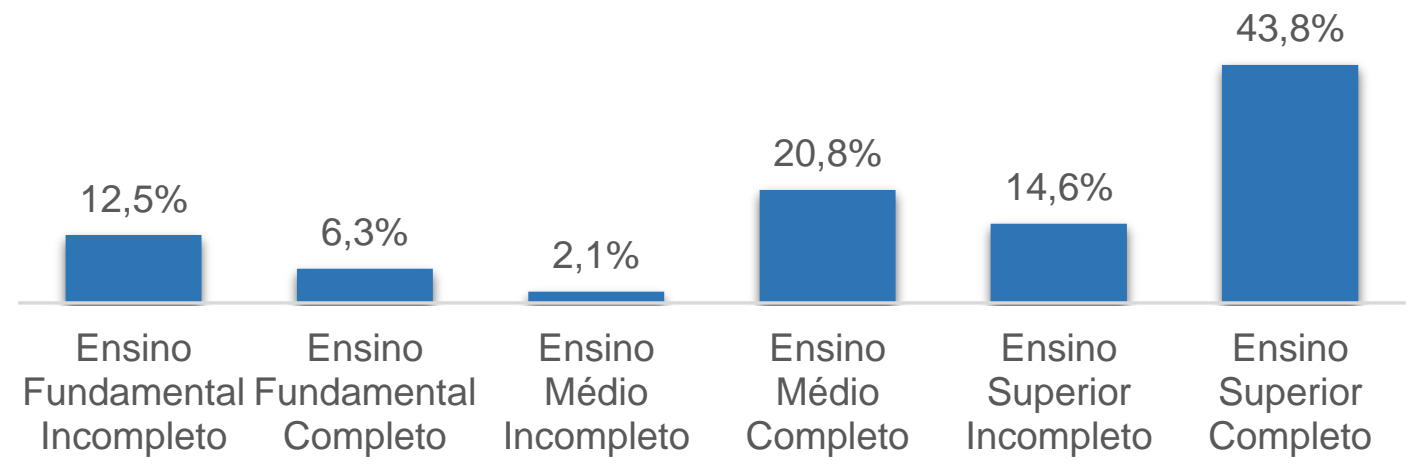

Gráfico 11 - Qual seu nível de escolaridade?

Fonte: Elaborado pela autora

\section{Já teve outros negócios?}

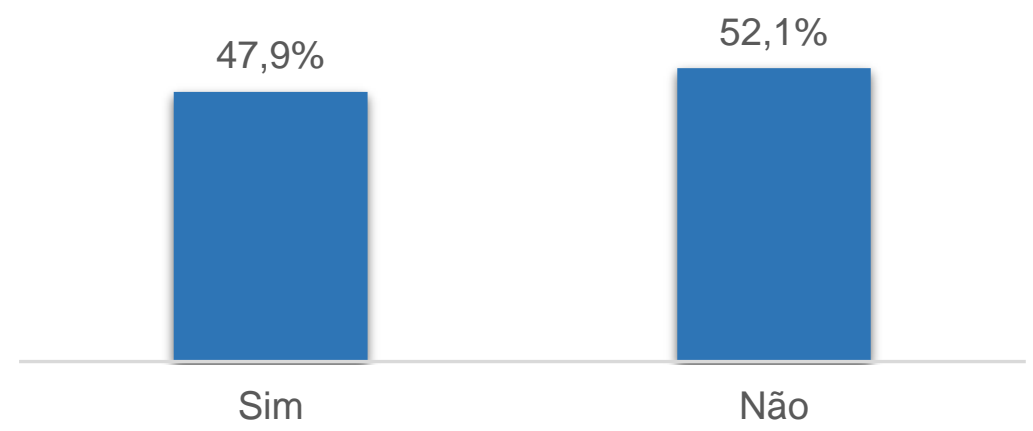

Gráfico 12 - Já teve outros negócios?

Fonte: Elaborado pela autora 


\section{Por que fechou?}

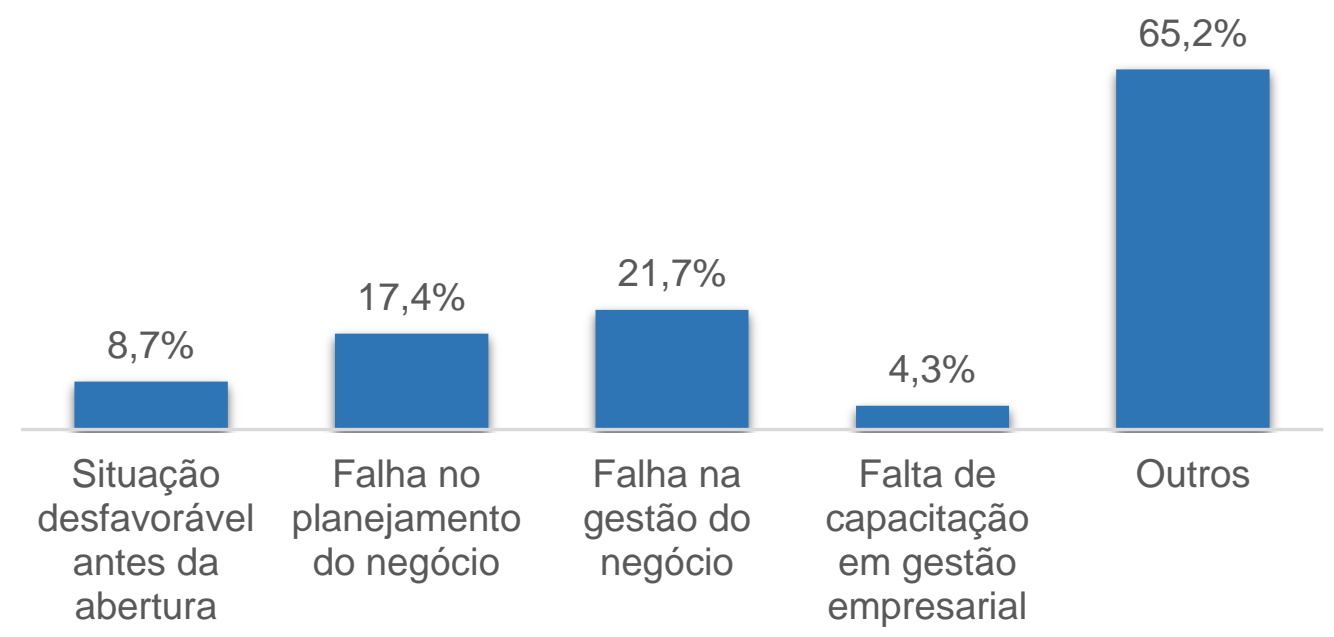

Gráfico 13 - Por que fechou?

Fonte: Elaborado pela autora

\section{Como se qualificou para fazer a gestão do negócio?}

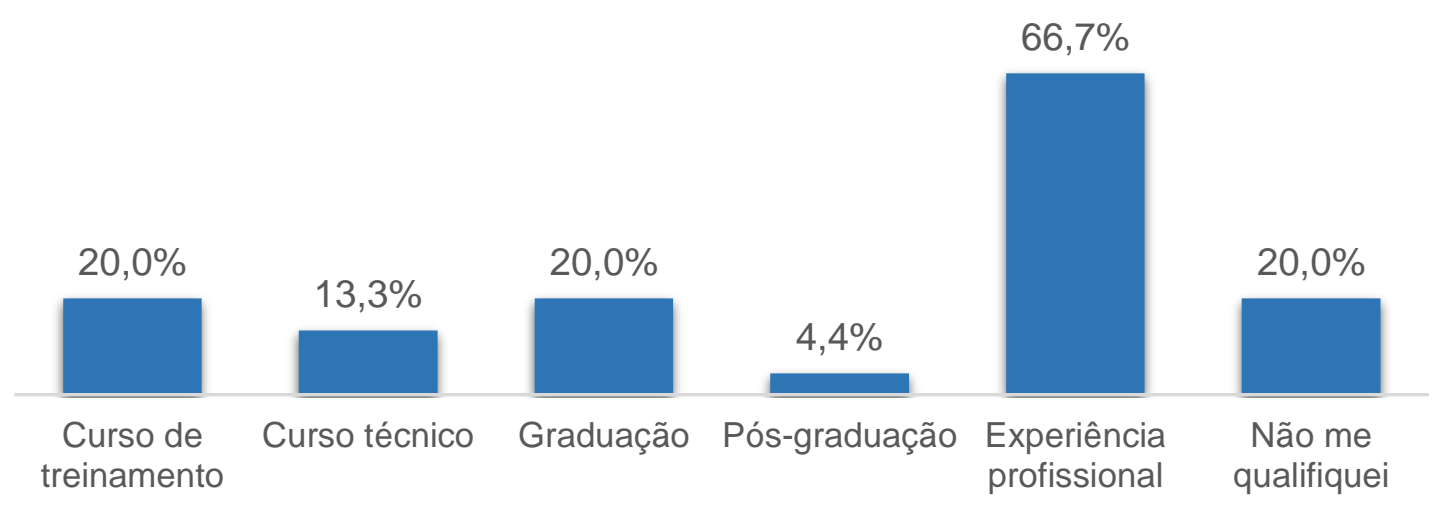

Gráfico 14 - Como se qualificou para fazer a gestão do negócio?

Fonte: Elaborado pela autora 


\section{Você separa as contas da empresa de suas contas pessoais?}

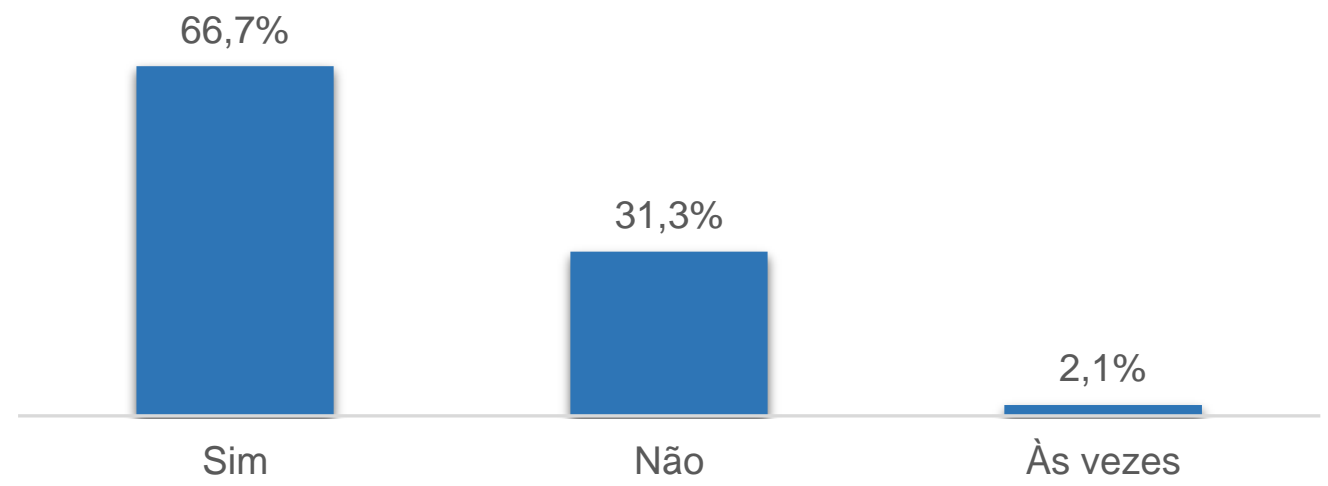

Gráfico 15 - Você separa as contas da empresa de suas contas pessoais? Fonte: Elaborado pela autora

\section{Quem faz a gestão financeira do negócio?}

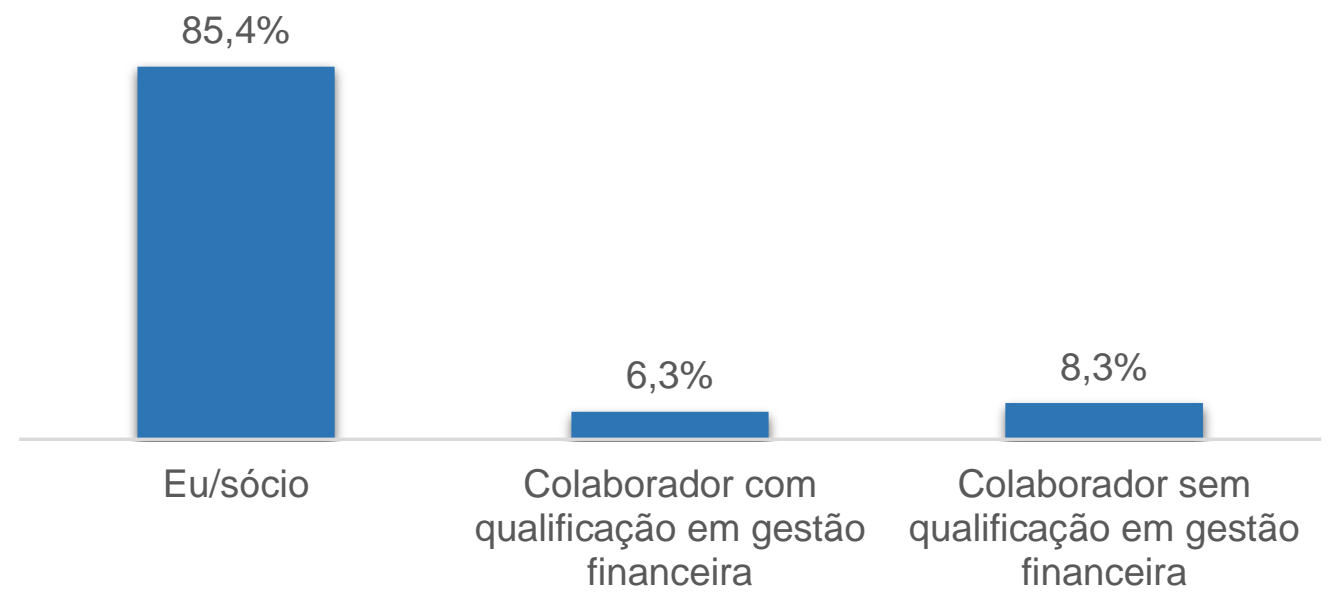

Gráfico 16 - Quem faz a gestão financeira do negócio?

Fonte: Elaborado pela autora 


\section{As demonstrações financeiras são utilizadas para gerenciar o negócio?}

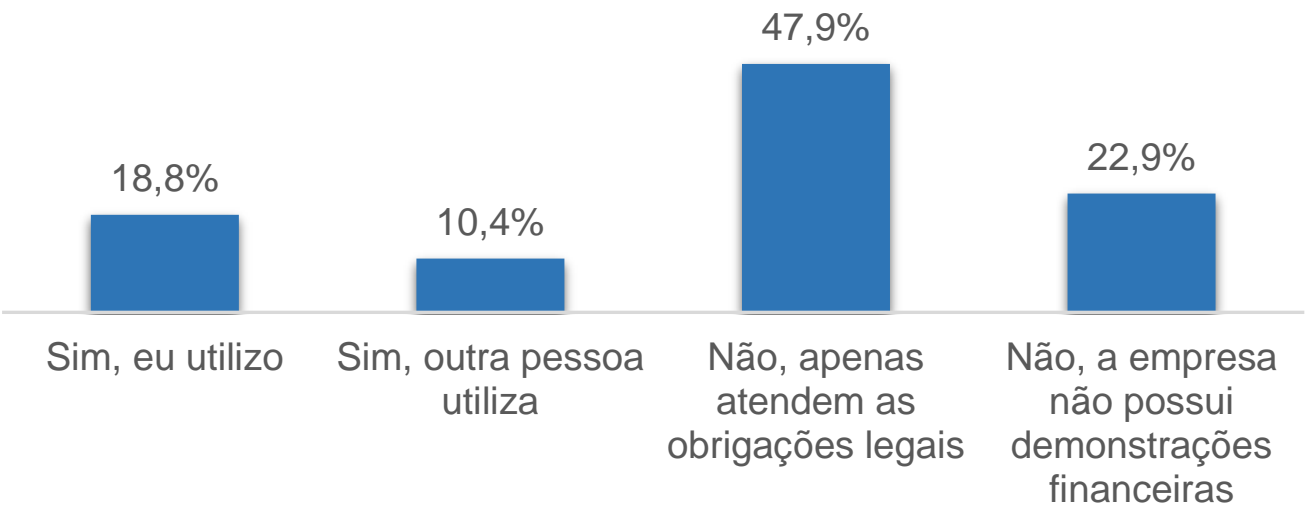

Gráfico 17 - As demonstrações financeiras são utilizadas para gerenciar o negócio? Fonte: Elaborado pela autora

\section{Como você faz seu planejamento financeiro pessoal?}

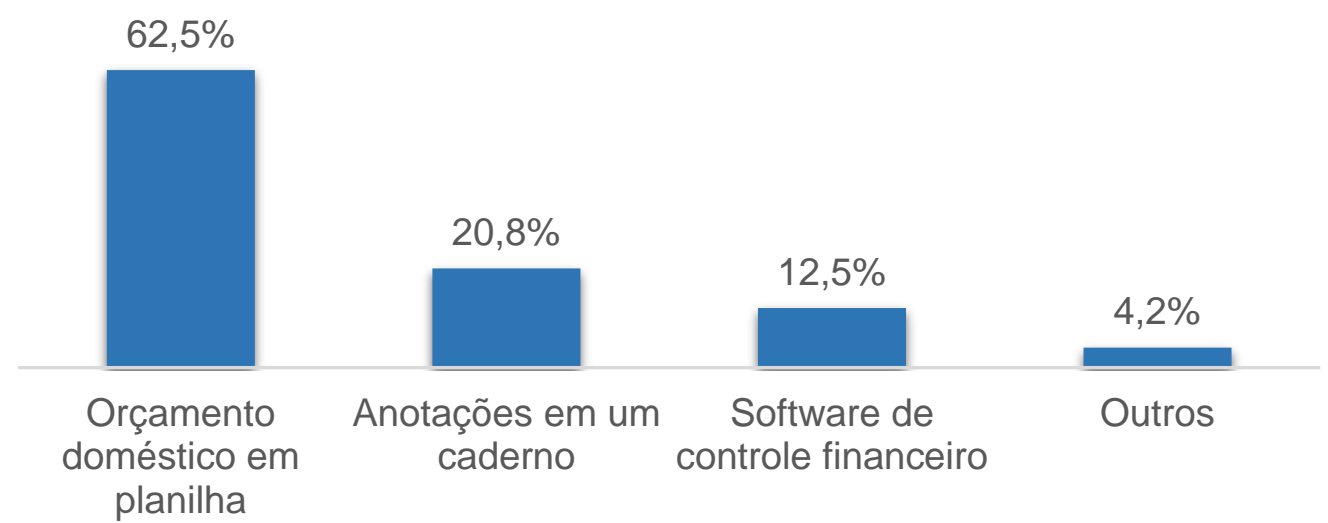

Gráfico 18 - Como você faz seu planejamento financeiro pessoal?

Fonte: Elaborado pela autora 


\section{Quanto você se considera qualificado para fazer a gestão financeira do seu negócio?}

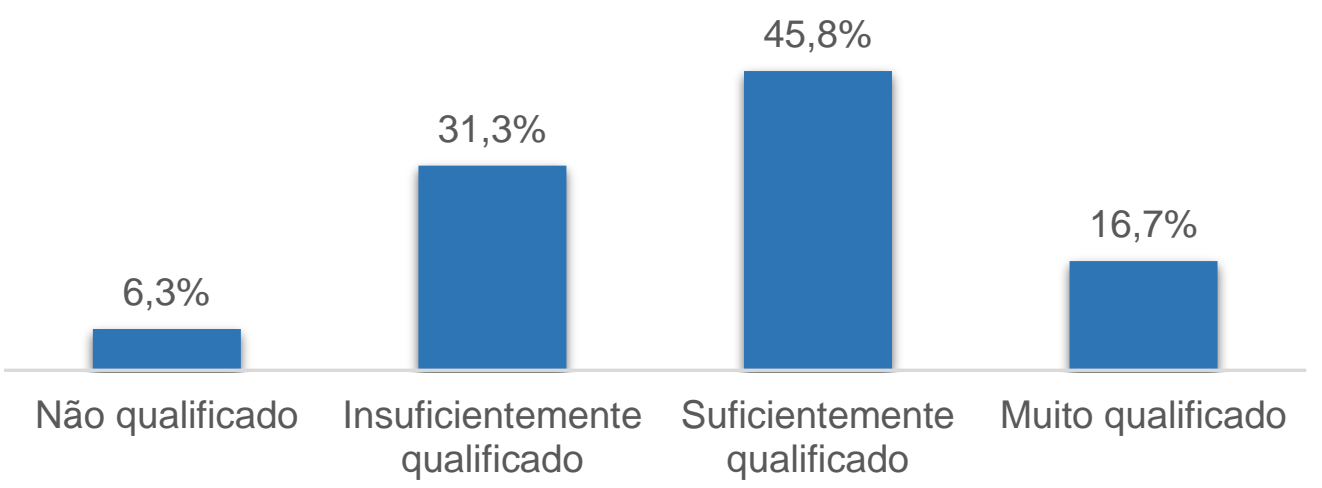

Gráfico 19 - Quanto você se considera qualificado para fazer a gestão financeira do seu negócio? Fonte: Elaborado pela autora

\section{Quanto você se considera qualificado para fazer uma boa gestão das suas finanças pessoais?}

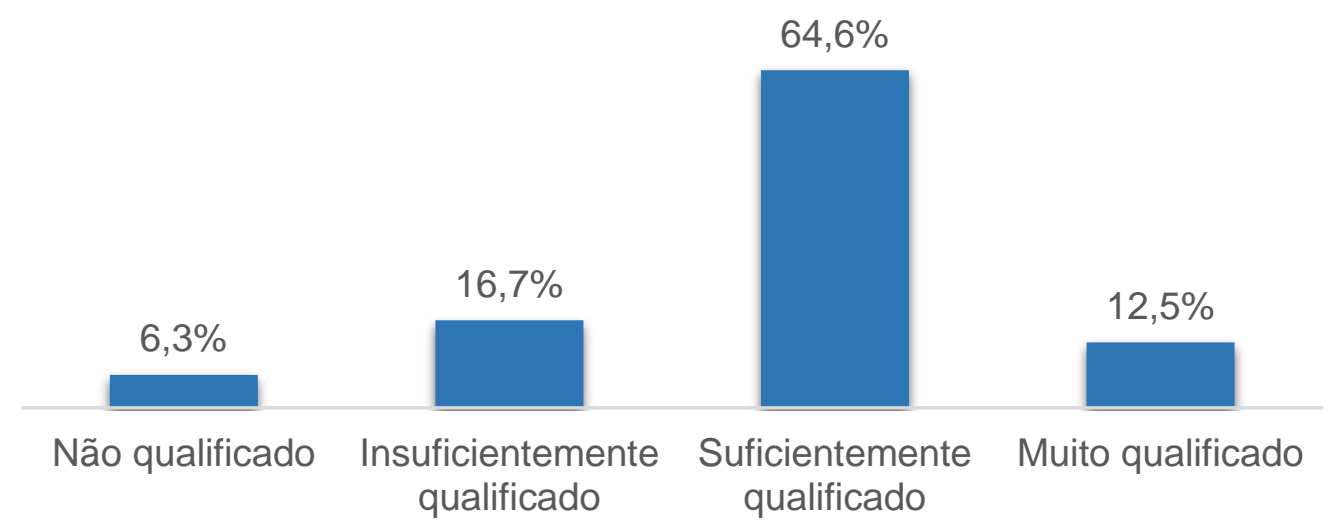

Gráfico 20 - Quanto você se considera qualificado para fazer uma boa gestão das suas finanças pessoais?

Fonte: Elaborado pela autora 


\section{A empresa possui dívidas?}

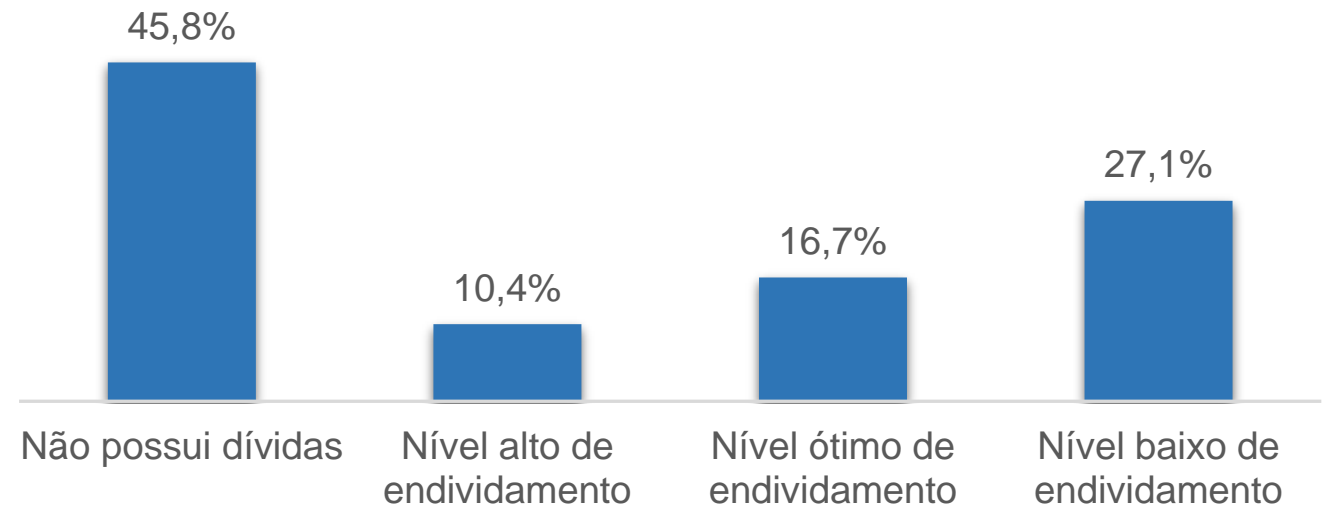

Gráfico 21 - A empresa possui dívidas?

Fonte: Elaborado pela autora

\section{Você possui dívidas?}

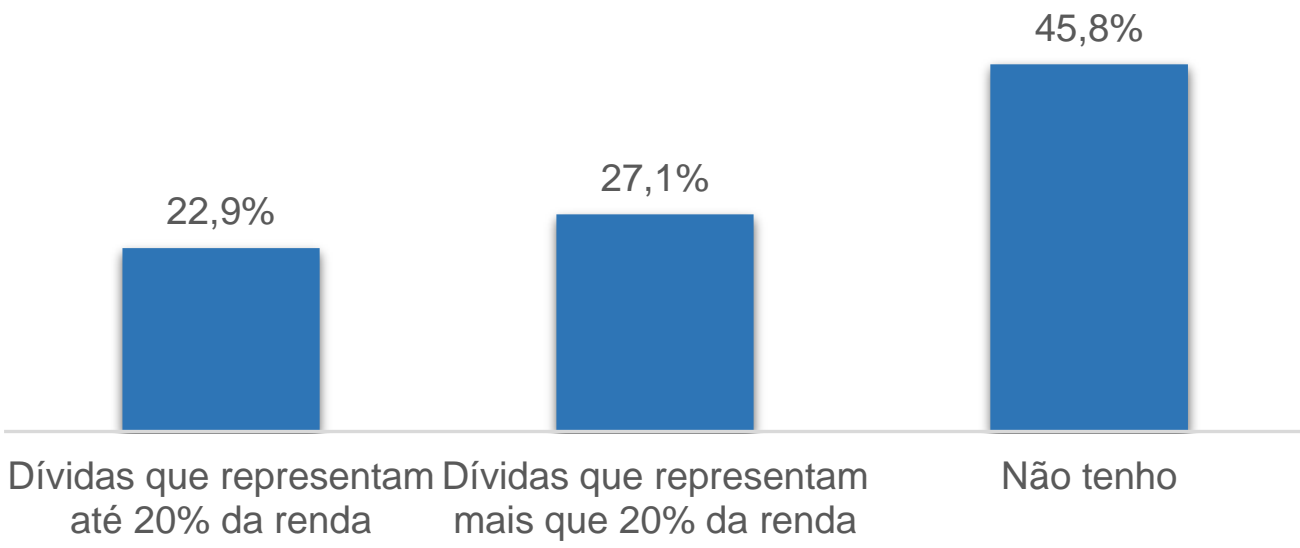

Gráfico 22 - Você possui dívidas?

Fonte: Elaborado pela autora 


\section{A empresa possui dívidas em atraso?}

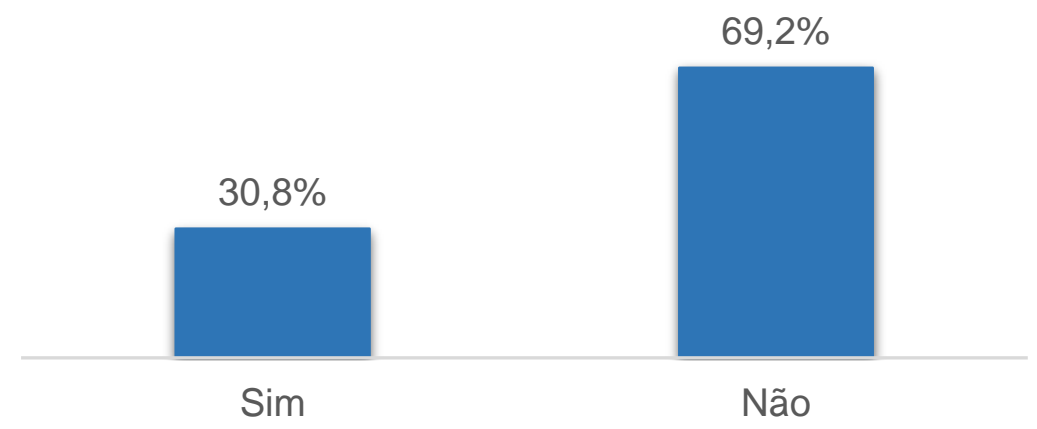

Gráfico 23 - A empresa possui dívidas em atraso? Fonte: Elaborado pela autora

\section{Você possui dívidas em atraso?}

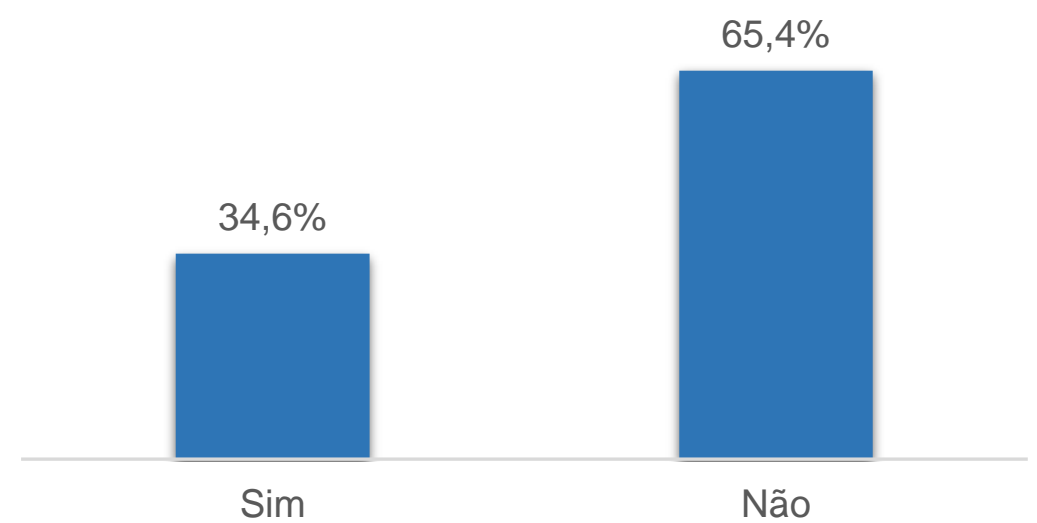

Gráfico 24 - Você possui dívidas em atraso? Fonte: Elaborado pela autora

\section{A empresa possui algum tipo de investimento financeiro? Se sim, qual(is)?}

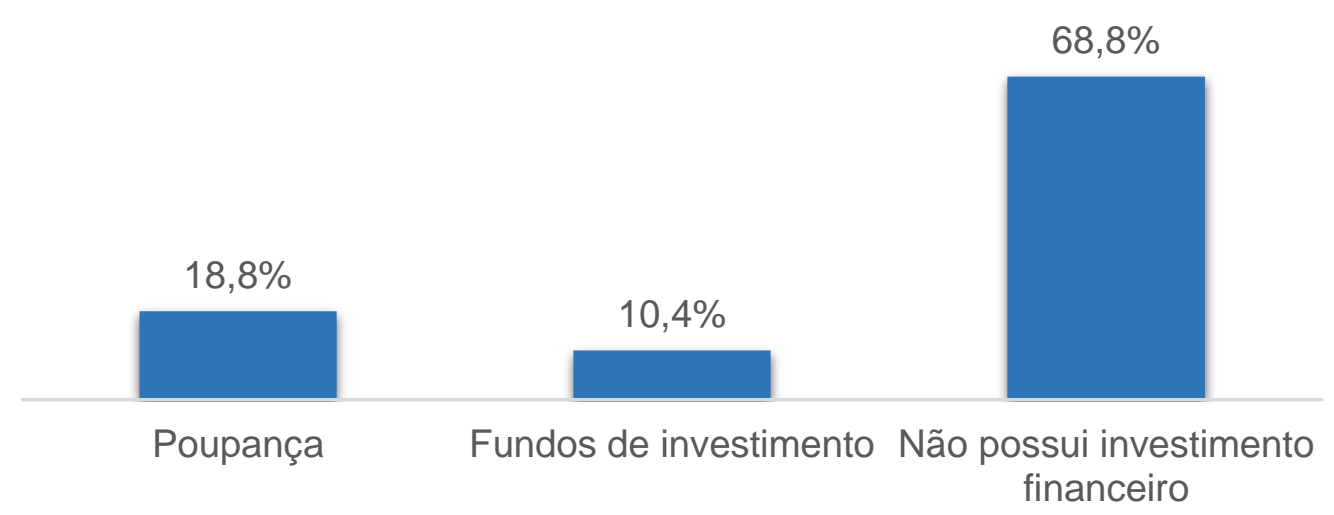

Gráfico 25 - A empresa possui algum tipo de investimento financeiro? Se sim, qual(is)? Fonte: Elaborado pela autora 


\section{Você possui algum tipo de investimento financeiro? Se sim, qual(is)?}

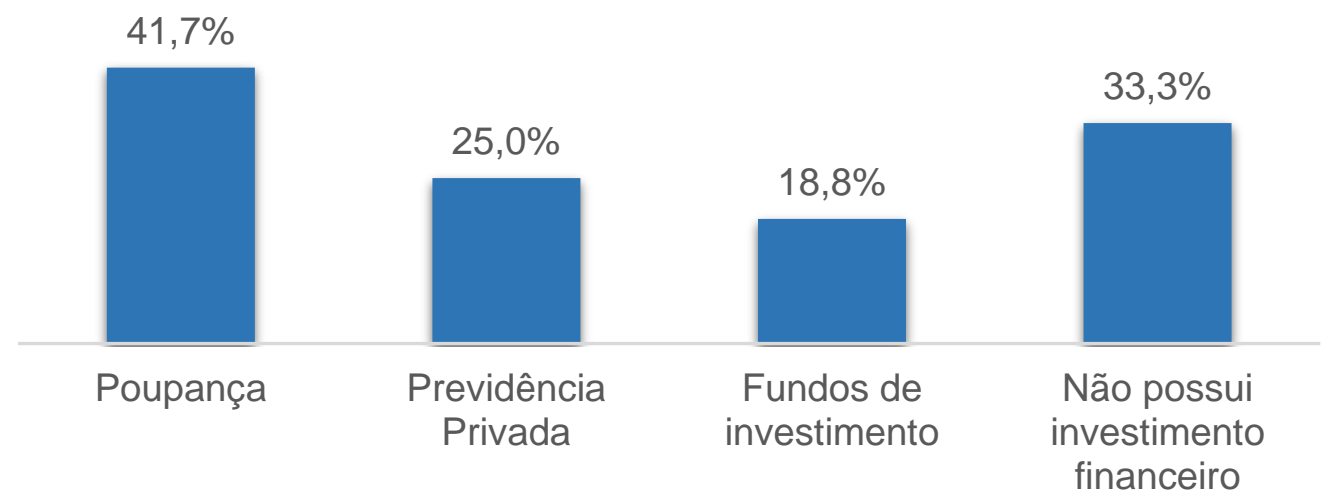

Gráfico 26 - Você possui algum tipo de investimento financeiro? Se sim, qual(is)? Fonte: Elaborado pela autora

\section{Qual a finalidade dos investimentos financeiros da empresa?}

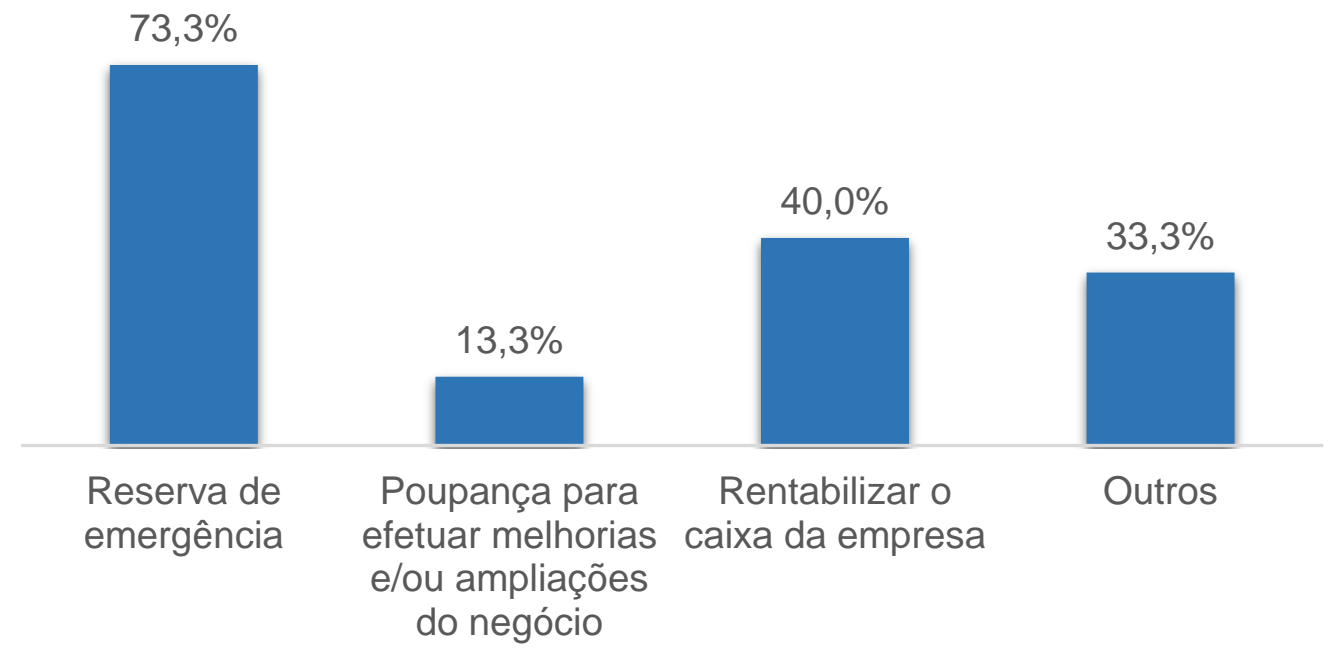

Gráfico 27 - Qual a finalidade dos investimentos financeiros da empresa? Fonte: Elaborado pela autora 


\section{Qual a finalidade dos investimentos financeiros pessoais?}

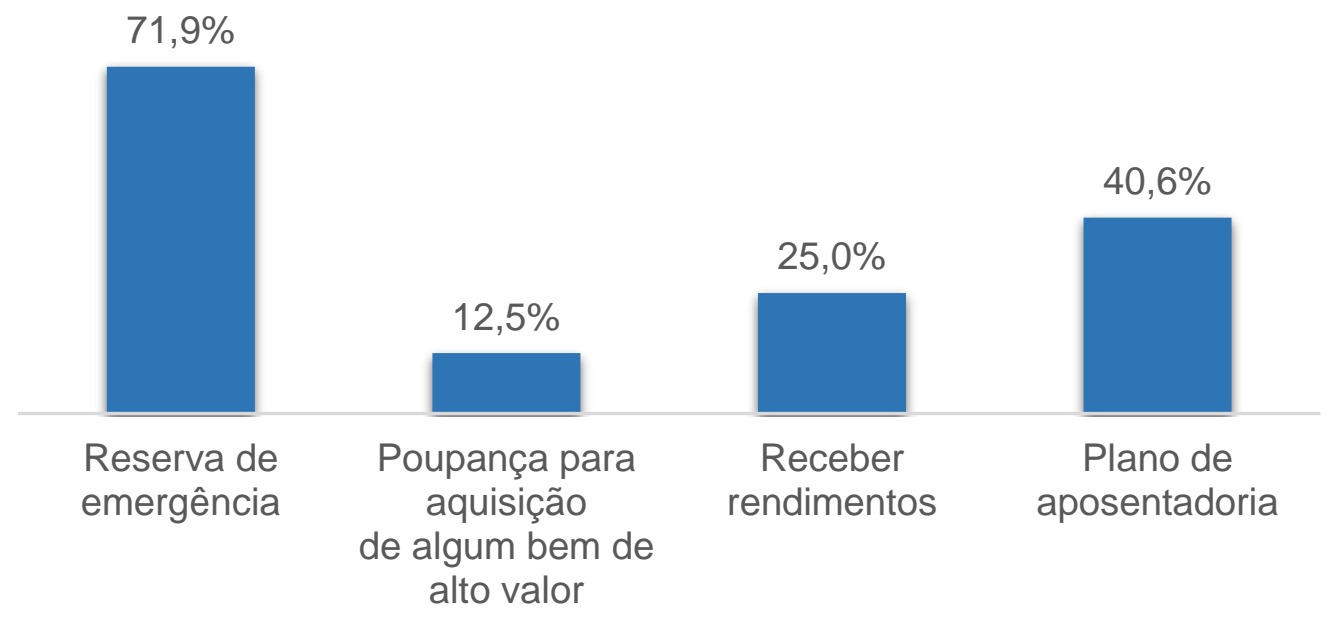

Gráfico 28 - Qual a finalidade dos investimentos financeiros pessoais? Fonte: Elaborado pela autora 